\title{
Assessment of potential benefits of traffic and urban mobility reductions during COVID-19 lockdowns: dose-response calculations for material corrosions on built cultural heritage
}

\author{
Parya Broomandi $^{1,2} \cdot$ Aidana Tleuken $^{1} \cdot$ Shaikhislam Zhaxylykov $^{1} \cdot$ Amirhossein Nikfal $^{3} \cdot$ Jong Ryeol Kim $^{1}$. \\ Ferhat Karaca ${ }^{1}$
}

Received: 7 April 2021 / Accepted: 17 August 2021 / Published online: 28 August 2021

(C) The Author(s), under exclusive licence to Springer-Verlag GmbH Germany, part of Springer Nature 2021

\begin{abstract}
Air pollution, particularly in urban areas, puts human health in danger and has adverse impacts on the built environment. It can accelerate the natural corrosion rate of cultural heritages and monuments, leading to premature aging and lowering their aesthetic value. Globally, at the beginning of 2020, to tackle the spread of novel COVID-19, the lockdown was enforced in the most hardhit countries. Therefore, this study assesses, as a first time, the plausible benefits of traffic and urban mobility reductions on the natural process of deterioration of materials during COVID-19 lockdown in twenty-four major cities on five continents. The potential risk is estimated based on exceeding the tolerable degradation limits for each material. The notable impact of COVID-19 mobility restrictions on air quality was evidenced in 2020 compared to 2019. The introduced mobility restrictions in 2020 could decrease the surface recession rate of materials. Extremely randomized trees analysis showed that $\mathrm{PM}_{10}$ was the main influencing factor for corrosion of portland, copper, cast bronze, and carbon steel with a relative importance of $0.60,0.32,0.90$, and 0.64 , respectively, while $\mathrm{SO}_{2}$ and $\mathrm{HNO}_{3}$ were mainly responsible for corrosion of sandstone and zinc with a relative importance of 0.60 and 0.40 , respectively. The globally adverse governed meteorological conditions in 2020 could not positively influence the movement restrictions around the world in air quality improvements. Our findings can highlight the need for additional policies and measures for reducing ambient pollution in cities and the proximity of sensitive cultural heritage to avoid further damage.
\end{abstract}

Keywords Multi-pollutant risk assessment $\cdot$ Cultural heritage conservation $\cdot$ Air pollution $\cdot$ Atmospheric corrosion $\cdot$ Coronavirus

\section{Introduction}

The outbreak of COVID-19 has turned into a pandemic leading to quarantine measures in most countries, and it has influenced many aspects of life such as the economy, tourism, environment, medicine, and business. While most of the

\section{Responsible Editor: Michel Sablier}

Ferhat Karaca

ferhat.karaca@nu.edu.kz; fkaraca1974@gmail.com

1 Department of Civil and Environmental Engineering, School of Engineering and Digital Sciences, Environment and Resource Efficiency Cluster (EREC), Nazarbayev University, Kabanbay Batyr Ave. 53, Nur-Sultan, Kazakhstan 010000

2 Department of Chemical Engineering, Masjed-Soleiman Branch, Islamic Azad University, Masjed-Soleiman, Iran

3 Atmospheric Science and Meteorological Research Center, Tehran, Iran consequences of pandemics are negative, there are also positive consequences of protective measures against COVID-19. One of these positive influences is the reduction of the detrimental effects of anthropogenic impacts on built cultural heritage in large cities.

Built cultural heritage conservation is gaining attention due to its substantial contribution to history and cultural identity. Therefore, humanity is significantly concerned about preserving the built heritage for the better pleasure of present and future populations. However, preservation of heritage and the urge for modernization frequently interrupt each other, which creates a challenge for humanity (González Martínez 2017). Cultural built heritage, apart from aging, can be impacted by different factors, such as static-structural hazards (e.g., earthquakes or floods), environmental-air hazards (i.e., air pollution or weathering), and anthropogenic hazards (e.g., tourism or fires) (Ortiz et al. 2014). 
Air pollution is the most severe environmental factor on the built cultural heritage as it can cause substantial deterioration of the materials and shorten their lifetime (Ivaskova et al. 2015; Vidal et al. 2019). Industrial growth has increased the utilization amount of fossil fuels that emit nitrogen and sulfur dioxides into the atmosphere, which, in turn, they can deposit on surfaces, react with other pollutants, and cause acid rain (Venkat Rao et al. 2016). Acid rain is claimed to be the primary cause of heritage buildings' degradation (Venkat Rao et al. 2016). Physically, the deterioration can occur in shapes of material disintegration, structural failing, loss of color, and corrosion. It leads to cultural loss and significant financial expenses required for repair and renovation (Ortiz et al. 2014).

Deterioration of the building materials by air pollution occurs in two ways: first, by the deposition of gases, which cause corrosion, and second, soiling by black particles, which stain surfaces (Vidal et al. 2019; Watt et al. 2009). Different atmospheric pollutants have various effects on the building materials. For example, sulfur dioxide $\left(\mathrm{SO}_{2}\right)$, especially in combination with ozone $\left(\mathrm{O}_{3}\right)$ and nitrogen dioxide $\left(\mathrm{NO}_{2}\right)$, is the primary cause of corrosion and stone decay (Watt et al. 2009), nitric acid has solid acidic effects on the building materials (Kucera and Fitz 1995), whereas particulate matter (PM) causes soiling and adds up to corrosion (Kucera and Fitz 1995; Watt et al. 2009). Building materials are subject to different types of degradation. Metals (e.g., steel, copper, bronze) and glass are prone to corrosion, while concrete (including different mortar types) is strongly susceptible to air pollution, which accelerates chemical reactions causing deterioration.

Current research efforts on cultural built heritage conservation are being divided into several directions: damage prediction (e.g., mapping, dose-response functions), conservation technologies applied directly to heritage sites (e.g., coating), and mitigation policies. Maps predicting climate changes and atmospheric corrosion are gaining attention to better develop heritage management and account for financial expenses (Brimblecombe et al. 2020; Federal Environmental Agency 2004; Vidal et al. 2019). Vidal et al. suggest using doseresponse functions (i.e., damage functions) in heritage conservation planning, as they allow consideration of environmental characteristics for corrosion and soiling maps (Vidal et al. 2019). Preservation techniques include mechanical or chemical corrosion removal, artificial patination, and protective coating with hydrophobic and chemical-resistant layers (e.g., particular types of waxing) (Knotkova and Kreislova 2007). When transported to water and soil, copper corrosion is highly harmful to the environment, in which mitigation also leads to high financial expenses (Knotkova and Kreislova 2007). Several studies argue that transportation systems working on combustible fuel are responsible for heavy metal releasement near historical heritage, causing severe deterioration (Comite et al. 2020; Comite and Fermo 2018; La Russa et al. 2018;
Rovella et al. 2020). As a mitigation measure, urban policies should focus on green modes of transport for decreasing particulate matter emissions from conventional transport (Baltrenas et al. 2017). Despite the fact that regulations in several countries limit the ambient levels of $\mathrm{SO}_{2}$, still air pollution caused by transportation systems which are working on combustible fuels is still a challenge for the worldwide built cultural heritage (Ivaskova et al. 2015; Vidal et al. 2019). Due to regulated limits of $\mathrm{SO}_{2}$ emissions, limestone structures are claimed to be easier to conserve and to have a more optimistic future, in contrast to metal structures which are found to be more challenging to preserve, as their corrosion, besides sulfur dioxide, is also dependent on other factors, such as temperature, humidity, and rain (Di Turo et al. 2016).

The COVID-19 pandemic has drastically changed the lifestyle of people worldwide by forcing them to stay at home to prevent disease propagation. Thus, global quarantines due to COVID-19 have led to minimization of tourism activities leading to less physical impacts (Gössling et al. 2020; Uğur and Akbıyık 2020) and limited urban traffic activities leading to potentially less air pollution-related corrosions on outdoor materials (Kerimray et al. 2020). This has potentially changed the anthropogenic and air hazard factors on the built cultural heritage. Particularly, the consequences of the pandemic have led to positive improvements in air quality worldwide: $\mathrm{CO}$, $\mathrm{NO}_{2}$, atmospheric particles $\left(\mathrm{PM}_{10}\right.$ and $\left.\mathrm{PM}_{2.5}\right)$, and $\mathrm{SO}_{2}$ concentrations have significantly decreased during the quarantine period, which led to overall multiple pollution reductions in annual pollution levels in urban environments compared to casual times (Aydın et al. 2020; Chen et al. 2021; Kerimray et al. 2020; Zambrano-Monserrate et al. 2020).

The pandemic conditions have increased virtual reality technologies in every part of urban life, including cultural heritage monitoring (Ren and Chen 2020). Since cultural accessibility is one of the fundamental human rights, some researchers have researched the accessibility of cultural heritage in virtual reality due to limited accessibility (Kużelewska and Tomaszuk 2020). For example, as a virtual touristic destination, museums and libraries have seen a sharp rise (Agostino et al. 2020; Atkinson 2020; Grant 2020; Temiz and Salelkar 2020). They also gain more attention than heritage sites in the latest cultural reviews (Bloom 2020; Jones 2020), which can be linked to availability, i.e., virtual reality tours are more developed for museums and galleries rather than for heritage sites.

Most of the recently developing literature on the pandemic conditions and cultural heritage focuses on building museums and galleries. To the best of our knowledge, any published study yet to exist evaluating the potential corrosion reductions on materials - due to the minimization of traffic and tourism activities during the lockdowns - with a specific focus on the cultural heritage objects. Despite the positive aspects of minimized tourism (such as decreases in air pollution and tourist 
pressure), tourism reduction can negatively affect financial assets spent on heritage sites' caring and maintenance. As pandemics are predicted to occur more frequently in the future (Tleuken et al. 2021), aspects of either virtual tourism or lack of visiting tours should also be carefully considered in developing heritage management plans.

This study aims to define the effect of pandemic-related air quality improvement on cultural heritage and identify whether there is a positive influence on deterioration delay. The COVID-19 lockdowns and measures provided us a unique opportunity to test how traffic reductions and urban mobility restrictions could reduce air pollution's negative impacts on the built environment. For that, the current study analyzes the potential deterioration levels of materials in several cities, which have numerous cultural heritage stocks and are listed as UNESCO cultural heritage centers from all the continents, bases on air pollution and other meteorological data profiles for the periods before and during quarantines, and compares the obtained results. These findings can help understand and develop strategies for the conservation of heritage buildings in a post-pandemic period and help develop better urban management plans.

\section{Methodology}

\section{City selection}

Twenty-four major cities were selected, representing all continents except Antarctica and Australia (Figure 1). The cities are Istanbul (Turkey), Beijing (China), Tokyo (Japan), Seoul (South Korea), Tehran (Iran), Delhi (India), Tel Aviv (Israel), Almaty (Kazakhstan), and Turkestan (Kazakhstan) in Asia; Paris (France), Rome (Italy), London (UK), Madrid (Spain), Berlin (Germany), Amsterdam (Netherlands), Warsaw (Poland), and Moscow (Russia) in Europe; New York City (USA), Los Angeles (USA), Sao Paulo (Brazil), Mexico
City (Mexico), and Santiago (Chile) in North America and South America; and Johannesburg (South Africa) in Africa. These cities are selected based on (1) data availability and accessibility, (2) representatives of large city characteristics in the selected part of the world, and (3) listed in the UNESCO cultural heritage centers.

\section{Air quality and meteorological data}

Air quality data, i.e., daily concentrations of $\mathrm{NO}_{2}, \mathrm{SO}_{2}, \mathrm{O}_{3}$, and $\mathrm{PM}_{10}$ (particles with an aerodynamic diameter less than ten microns), were obtained for 24 studied cities (Figure 1) and listed in Table S1, together with the data sources in 2019 and 2020.

Meteorological data, i.e., daily averages of rainfall ( $\mathrm{mm})$, temperature $\left({ }^{\circ} \mathrm{C}\right)$, and relative humidity (\%) from https:// www.ogimet.com/gsynres.phtml.en, were employed to calculate the annual average of temperature $\left({ }^{\circ} \mathrm{C}\right)$, relative humidity $(\%)$, as well as total annual precipitation $(\mathrm{mm})$ in 2019 and 2020. However, for the cities not included in the website, ERA5 reanalysis daily based data, produced by $\mathrm{C} 3 \mathrm{~S}$ at ECMWF, as the current atmospheric reanalysis and based on a 2016 version of the Integrated Forecasting System (IFS), was employed to complete the calculations.

\section{Data pre-processing}

At this step, missing values were removed or replaced with neighbors' averages (when practical). Also, the outliers were identified via a smoothing algorithm, which calculates moving averages with a specific rule (e.g., 3 days) by which data points are averaged within a neighborhood. It does not remove any high and abrupt increase but smothers it, ending with more statistically valid data. Only stations with available data above $75 \%$ were considered valid to assess in this work, and all the datasets were checked before averaging the concentrations of $\mathrm{NO}_{2}, \mathrm{SO}_{2}, \mathrm{O}_{3}$, and $\mathrm{PM}_{10}$. For some cities with hourly

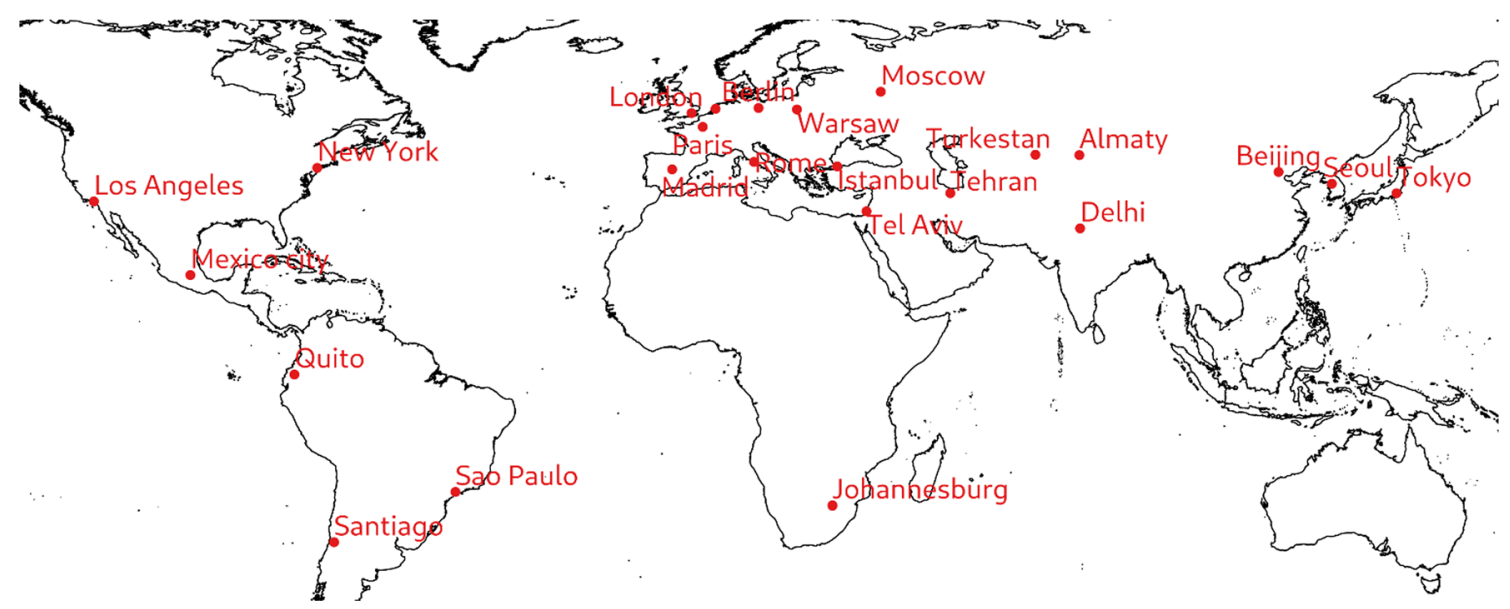

Figure 1 Twenty-four major cities impacted by COVID-19 are selected to study in the current study for 2019-2020 
concentrations of pollutants, only available data for $20 \mathrm{~h}$ a day were averaged, representing the daily $\mathrm{PM}_{2.5}$ concentration. Additionally, air quality data collected from https://aqicn. org/data-platform/covid19 did not report average values but median and range values. To estimate the average values based on median and range, the method developed by Hozo et al. (2005) was implemented here as below (Hozo et al. 2005):

$\bar{X}=\left(\frac{a+2 m+b}{4}\right)$

where $\bar{X}, \mathrm{a}, \mathrm{m}$, and $\mathrm{b}$ were average, minimum, median, and maximum values of observation, respectively.

\section{Estimation of rainwater $\mathrm{pH}$}

In urban areas, the rainwater acidity is mainly caused by the dissolution of nitrogen and sulfur oxides within the rain. Previous studies showed that only $\mathrm{SO}_{2}$ and $\mathrm{CO}_{2}$ contributed toward great $\mathrm{H}^{+}$ion contribution, and a correction factor for PM (particulate matter) was included to make theoretical $\mathrm{pH}$ values more representative of the real-world picture (Kita et al. 2004; Singh et al. 2016). Equation 1 was suggested based on the ambient concentrations of $\mathrm{SO}_{2}$ and $\mathrm{CO}_{2}$ and $\mathrm{pH}$ of particulate matter (2nd term on the left of Eq. 2). Subsequent wet deposition equations and constants (e.g., for $\mathrm{SO}_{2}$ and $\mathrm{CO}_{2}$ ) for the estimation of rainwater $\mathrm{pH}$ are also obtained from Eq. 2 (Singh et al. 2016) and summarized in Table 1.

$\left[\mathrm{H}^{+}\right]+25.12\left[\mathrm{H}^{+}\right]=\left[\mathrm{HCO}_{3}^{-}\right]+\left[\mathrm{HSO}_{3}^{-}\right]$

\section{Dose-response functions}

In the current study, multi-pollutant dose-response functions are applied for a range of materials (e.g., sandstone, copper, limestone, carbon steel, bronze, and zinc) to describe the relationship between weather parameters and pollutant concentrations, and they predict the deterioration rate of those structural materials used in the built environment. The employed doseresponse functions are listed in Table 2, and they are obtained from the EU project MULTI-ASSESS (Kucera 2005), the ICP Materials exposure program (Kucera et al. 2007; Tidblad et al. 2001), and Lombardo et al. (2010) (Lombardo et al. 2010). The input of dose-response functions includes annual means of pollutant concentrations and weather parameters, while the output is annual mean values of corrosion rate $(\mathrm{R}, \mu \mathrm{m})$. The corrosion rate, corrosion depth, or surface recession is the displacement of a point on the material's corroded surface concerning its initial position on the non-corroded surface taken as the reference point. Deterioration rates can also be expressed in terms of mass loss $\left(\mathrm{g} / \mathrm{m}^{2}\right)$. Mass loss (ML) can be converted into corrosion rate (R) by dividing ML by the density of the material $\left(\mathrm{g} / \mathrm{cm}^{3}\right)$.

\section{Statistical analysis}

Extremely randomized trees analysis (ET) was used in the current study to evaluate the relative importance of predictors including pollutants $\left(\mathrm{SO}_{2}, \mathrm{NO}_{2}, \mathrm{HNO}_{3}, \mathrm{O}_{3}, \mathrm{PM}_{10}, \mathrm{pH}\right)$ and environmental parameters (temperature, rainfall, relative humidity) affecting materials surface corrosion (Sicard et al. 2016). Extremely randomized trees analysis helps us to select the most important predictors affecting the response based on a classification from zero (no importance) to one (highest importance) (Di Turo et al. 2016; Vitale et al. 2014).

\section{Results and discussions}

\section{Changes in the concentrations of pollutants in studied cities around the world}

The notable impact of COVID-19 mobility restrictions on air quality was found in 24 major cities around the world, including significant decreases in the values of $\mathrm{PM}_{10}, \mathrm{NO}_{2}$, and $\mathrm{SO}_{2}$ and increases of ground-level $\mathrm{O}_{3}$ in most cities (Tables 3-4 and Figures 2-4). It is worth mentioning that, in the figures, $\mathrm{AOD}$ is representing $\mathrm{PM}_{10}$.

Table 1 Equations and constants for the estimation of rainwater pH (Singh et al. 2016)

\begin{tabular}{|c|c|c|c|}
\hline \multirow[t]{2}{*}{ Pollutant } & \multirow[t]{2}{*}{ Equations } & \multicolumn{2}{|l|}{ Constants } \\
\hline & & $\begin{array}{l}\text { Henry's } \\
\text { constant }\end{array}$ & $\begin{array}{l}\text { Equilibrium } \\
\text { constant }\end{array}$ \\
\hline $\mathrm{SO}_{2}$ & $\begin{array}{l}\mathrm{SO}_{2}(g)+\mathrm{H}_{2} \mathrm{O}(\mathrm{l}) \rightleftharpoons \mathrm{HSO}_{3}^{-}+\mathrm{H}^{+} \\
\mathrm{HSO}_{3}^{-} \rightleftharpoons \mathrm{SO}_{3}^{2-}+H^{+}\end{array}$ & $10^{0.096}$ & $\begin{array}{l}\mathrm{K}_{\mathrm{a} 1=10^{-1.77}} \\
\mathrm{~K}_{\mathrm{a} 2=10^{-7.21}}\end{array}$ \\
\hline $\mathrm{CO}_{2}$ & $\begin{array}{l}\mathrm{CO}_{2}(\mathrm{~g})+\mathrm{H}_{2} \mathrm{O}(\mathrm{l}) \rightleftharpoons \mathrm{HCO}_{3}^{-}+\mathrm{H}^{+} \\
\mathrm{HCO}_{3}^{-} \rightleftharpoons \mathrm{CO}_{3}^{2-}+\mathrm{H}^{+}\end{array}$ & $10^{-47}$ & $\begin{array}{l}\mathrm{K}_{\mathrm{a} 1=10^{-6.35}} \\
\mathrm{~K}_{\mathrm{a} 2=10^{-10.33}}\end{array}$ \\
\hline
\end{tabular}


Table 2 Dose-response functions for the deterioration of materials caused by air pollution (Di Turo et al. 2016; Karaca 2013; Kucera et al. 2007; Lombardo et al. 2010; Multi-Assess 2010; Spezzano 2021; Tidblad et al. 2001)

\begin{tabular}{|c|c|}
\hline Material/impact & Dose-response function \\
\hline Portland limestone/corrosion & $\begin{array}{l}R=4.0+0.0059\left[\mathrm{SO}_{2}\right] R h_{60}+0.054 \operatorname{Rain}\left[H^{+}\right]+0.078\left[\mathrm{HNO}_{3}\right] \\
\quad R h_{60}+0.0258 \mathrm{PM}_{10}\end{array}$ \\
\hline $\begin{array}{l}\text { White Mansfield dolomitic } \\
\text { sandstone/corrosion }\end{array}$ & $\begin{array}{l}R=2.0\left[\mathrm{SO}_{2}\right]^{0.52} e^{f(T)}+0.028 \boldsymbol{R} \operatorname{ain}\left[H^{+}\right] \\
f(T)=0 \text { when } T \leq 10^{\circ} \mathrm{C}, \text { otherwise } f(T)=-0.013(T-10)\end{array}$ \\
\hline Copper/corrosion & $\begin{array}{l}M L=4.2+0.00201\left[\mathrm{SO}_{2}\right] 0.4\left[\mathrm{O}_{3}\right] R h_{60} e^{f(T)}+0.0878 \boldsymbol{R} \operatorname{ain}\left[H^{+}\right] \\
f(T)=0.083(T-10) \text { when } T<10^{\circ} \mathrm{C}, \text { otherwise } f(T)=-0.032(T-10)\end{array}$ \\
\hline Cast bronze/corrosion & $\begin{array}{l}R=0.15+0.000985\left[S_{2}\right] R h_{60} e^{f(T)}+0.00465 \operatorname{Rain}\left[H^{+}\right]+0.00432 P M_{10} \\
f(T)=0.060(T-11) \text { when } T<10^{\circ} \mathrm{C}, \text { otherwise } f(T)=-0.067(T-11)\end{array}$ \\
\hline Carbon steel/corrosion & $\begin{array}{l}R=6.5+0.178\left[\mathrm{SO}_{2}\right]^{0.6} R h_{60} e^{f(T)}+0.166 \operatorname{Rain}\left[H^{+}\right]+0.076 P M_{10} \\
f(T)=0.15(T-10) \text { when } T<10^{\circ} \mathrm{C}, \text { otherwise } f(T)=-0.054(T-10)\end{array}$ \\
\hline Zinc/corrosion & $\begin{array}{l}R=0.49+0.066\left[\mathrm{SO}_{2}\right]^{0.22} e^{0.018 R h+f(T)}+0.0057 \operatorname{Rain}\left[H^{+}\right]+0.192\left[\mathrm{HNO}_{3}\right] \\
f(T)=0.062(T-10) \text { when } T<10^{\circ} \mathrm{C} \text {, otherwise } f(T)=-0.021(T-10)\end{array}$ \\
\hline
\end{tabular}

Where:

$R$ surface recession or corrosion depth, $\mu \mathrm{m}$, first year exposure

$M L$ mass loss, $\mathrm{g} / \mathrm{m}^{2}$

$R h$ annual average relative humidity, \%

$R h_{60} \mathrm{Rh}-60$ when $\mathrm{Rh}>60$ otherwise 0

Rain annual amount of precipitation (mm/year)

$T$ annual average temperature, ${ }^{\circ} \mathrm{C}$

$\left[\mathrm{SO}_{2}\right]$ annual average $\mathrm{SO}_{2}$ concentration, $\mu \mathrm{g} / \mathrm{m}^{3}$

$\left[\mathrm{HNO}_{3}\right]=516 * e^{-3400 /(T+273)} *\left(\left[\mathrm{NO}_{2}\right]\left[\mathrm{O}_{3}\right] R h\right)^{0.5}$ (annual $\mathrm{HNO}_{3}$ concentration, $\mu \mathrm{g} / \mathrm{m}^{3}$ )

$\left[\mathrm{O}_{3}\right]$ annual average $\mathrm{O}_{3}$ concentration, $\mu \mathrm{g} / \mathrm{m}^{3}$

[PM 10 ] annual average $\mathrm{PM}_{10}$ concentration, $\mu \mathrm{g} / \mathrm{m}^{3}$

$\left[\mathrm{H}^{+}\right]$annual average $\mathrm{H}^{+}$concentration in rain, $\mathrm{mg} / \mathrm{l}$

\section{Primary pollutants: $\mathrm{NO}_{2}$ and $\mathrm{SO}_{2}$}

$\mathrm{NO}_{2}$ concentration decreased for all cities but Almaty and Santiago (Tables 3-4 and Figure 2) during the COVID-19 period, compared to 2019. The highest decline was observed in Paris $(-86.6 \%)$, and the lowest was in Warsaw $(-3.3 \%)$ in comparison to 2019. In Almaty and Santiago, an increase of $3.4 \%$ and $5.7 \%$ was experienced, respectively.

The same decreasing trend was observed in $\mathrm{SO}_{2}$ levels in 17 cities, compared to 2019. The highest reduction occurred in Turkestan and Los Angeles with the percentage of 186 and 106 , respectively. However, in the other seven remaining cities, an increase was observed with the highest percentage of 60.0 in London and the lowest of $11.9 \%$ in Paris compared to 2019 (Tables 3-4 and Figure 3).

\section{Secondary pollutants: ground-level ozone}

Contrary to the declining general trends of primary pollutants $\left(\mathrm{NO}_{2}\right.$ and $\left.\mathrm{SO}_{2}\right)$, ground-level ozone has increased in 11 cities ranging from +0.63 to $+33.11 \%$ and reduced in the other 11 cities ranging from -0.98 to $-21.7 \%$, relative to 2019 . In Almaty and Turkestan, the ground-level $\mathrm{O}_{3}$ concentrations were not available for 2019 and 2020 to investigate the trend of changes (Tables 3-4 and Figure 4). Tehran experienced the maximum increase $(+33.1 \%)$, and Rome had the minimum increase $(+0.68 \%)$. On the other hand, Warsaw experienced a significant decrease $(-22.0 \%)$ relative to 2019 .

\section{Particulate matter: $\mathrm{PM}_{10}$}

$\mathrm{PM}_{10}$ had a reduction in all cities, except in Seoul, Tokyo, New York, Los Angles, and Rome, with an increase of $0.51 \%, 5.21 \%, 3.27 \%, 6.34 \%$, and $2.95 \%$, respectively, relative to 2019 (Tables 3-4 and Figure 5). There was a maximum decline in Moscow (-73.9\%), and the minimum decrease was experienced in Berlin (-4.17\%).

The experienced reduction in primary pollutants of $\mathrm{SO}_{2}$ and $\mathrm{NO}_{2}$ during the COVID-19 period relative to 2019 is caused by the decrease of emissions from anthropogenic activities, mainly urban transportation. The main reason behind the $\mathrm{NO}_{2}$ decline was the transportation reduction due to the restrictions in human mobility in most studied cities (Tables 3-4 and Figure 2) (Fu et al. 2020). The observed difference in air pollutant reduction between studied cities was mainly due to the different lockdown measures worldwide; in cities like Delhi, Beijing, and Almaty, a considerable decline in pollutants' level was observed (Fu et al. 2020; 
Table 3 The average annual concentrations of $\mathrm{SO}_{2}, \mathrm{NO}_{2}, \mathrm{O}_{3}$, and $\mathrm{PM}_{10}$ in 2019 and 2020 in the studied cities

\begin{tabular}{|c|c|c|c|c|c|c|c|c|c|}
\hline & \multirow[t]{2}{*}{ City } & \multicolumn{4}{|l|}{2019} & \multicolumn{4}{|l|}{2020} \\
\hline & & $\mathbf{P M}_{10}\left(\mu \mathrm{g} / \mathrm{m}^{3}\right)$ & $\mathbf{N O}_{2}\left(\mu \mathrm{g} / \mathrm{m}^{3}\right)$ & $\mathbf{S O}_{2}\left(\mu \mathrm{g} / \mathrm{m}^{3}\right)$ & $\mathbf{O}_{\mathbf{3}}\left(\mu \mathrm{g} / \mathrm{m}^{3}\right)$ & $\mathbf{P M}_{\mathbf{1 0}}\left(\mu \mathrm{g} / \mathrm{m}^{3}\right)$ & $\mathbf{N O}_{2}\left(\mu \mathrm{g} / \mathrm{m}^{3}\right)$ & $\mathbf{S O}_{2}\left(\mu \mathrm{g} / \mathrm{m}^{3}\right)$ & $\mathbf{O}_{\mathbf{3}}\left(\mu \mathrm{g} / \mathrm{m}^{3}\right)$ \\
\hline \multirow[t]{8}{*}{ Europe } & Amsterdam & $20.8 \pm 6.4$ & $15.4 \pm 6.9$ & $1.9 \pm 1.0$ & $17.6 \pm 6.4$ & $19.1 \pm 5.3$ & $13.2 \pm 5.5$ & $1.9 \pm 0.7$ & $19.1 \pm 4.8$ \\
\hline & Berlin & $22.5 \pm 10.6$ & $15.7 \pm 6.5$ & $2.4 \pm 1.2$ & $20.0 \pm 8.6$ & $21.6 \pm 10.1$ & $13.8 \pm 6.0$ & $2.4 \pm 3.1$ & $19.5 \pm 8.1$ \\
\hline & Moscow & $42.6 \pm 33.4$ & $16.6 \pm 11.1$ & $7.5 \pm 4.5$ & $10.7 \pm 4.8$ & $24.5 \pm 19.2$ & $10.0 \pm 6.7$ & $7.5 \pm 3.3$ & $11.4 \pm 5.1$ \\
\hline & Paris & $32.8 \pm 14.9$ & $24.1 \pm 14.7$ & $2.1 \pm 1.1$ & $18.7 \pm 7.5$ & $25.5 \pm 11.6$ & $12.9 \pm 7.9$ & $2.1 \pm 1.2$ & $23.7 \pm 9.5$ \\
\hline & Rome & $21.2 \pm 7.1$ & $13.8 \pm 6.4$ & $1.1 \pm 0.4$ & $18.8 \pm 6.6$ & $21.8 \pm 8.7$ & $11.4 \pm 9.2$ & $1.1 \pm 0.4$ & $18.9 \pm 7.4$ \\
\hline & Warsaw & $25.3 \pm 10.1$ & $21.5 \pm 11.7$ & $2.4 \pm 1.6$ & $47.1 \pm 32.4$ & $23.2 \pm 10.1$ & $20.8 \pm 12.8$ & $2.8 \pm 1.2$ & $38.7 \pm 25.2$ \\
\hline & London & $14.5 \pm 8.5$ & $27.3 \pm 12.5$ & $1.7 \pm 0.6$ & $46.5 \pm 17.0$ & $13.2 \pm 7.1$ & $20.3 \pm 9.6$ & $4.1 \pm 4.8$ & $54.8 \pm 18.7$ \\
\hline & Madrid & $20.9 \pm 9.5$ & $51.4 \pm 17.2$ & $7.9 \pm 2.5$ & $45.8 \pm 20.1$ & $19.2 \pm 8.6$ & $35.3 \pm 15.5$ & $6.9 \pm 2.9$ & $46.5 \pm 20.9$ \\
\hline \multirow[t]{9}{*}{ Asia } & Tehran & $50.8 \pm 14.6$ & $132.6 \pm 35.0$ & $13.8 \pm 3.4$ & $62.6 \pm 43.2$ & $45.9 \pm 12.3$ & $122.9 \pm 23.8$ & $31.7 \pm 26.4$ & $93.8 \pm 83.7$ \\
\hline & Beijing & $68.6 \pm 32.0$ & $23.1 \pm 10.9$ & $14.7 \pm 11.6$ & $29.1 \pm 17.3$ & $63.9 \pm 29.6$ & $19.2 \pm 11.0$ & $14.7 \pm 7.0$ & $28.2 \pm 16.0$ \\
\hline & Istanbul & $33.9 \pm 12.8$ & $67.8 \pm 16.0$ & $5.0 \pm 3.8$ & $24.8 \pm 13.0$ & $26.3 \pm 9.4$ & $56.2 \pm 17.9$ & $4.1 \pm 1.9$ & $21.1 \pm 10.2$ \\
\hline & Almaty & $50.8 \pm 22.6$ & $65.5 \pm 21.2$ & $128.1 \pm 87.5$ & NA & $47.5 \pm 29.0$ & $67.8 \pm 21.5$ & $72.2 \pm 91.4$ & NA \\
\hline & Turkestan & $45.1 \pm 42.6$ & $13.4 \pm 9.8$ & $21.1 \pm 16.4$ & NA & $33.0 \pm 36.9$ & $11.6 \pm 23.2$ & $7.3 \pm 9.9$ & NA \\
\hline & Tel Aviv & $37.4 \pm 23.8$ & $22.5 \pm 12.1$ & $1.8 \pm 1.5$ & $69.7 \pm 16.2$ & $28.8 \pm 12.5$ & $17.3 \pm 11.0$ & $2.9 \pm 0.9$ & $73.6 \pm 17.9$ \\
\hline & Seoul & $37.6 \pm 26.5$ & $61.8 \pm 30.8$ & $9.2 \pm 3.2$ & $54.7 \pm 43.7$ & $37.8 \pm 19.1$ & $48.0 \pm 25.7$ & $8.2 \pm 2.1$ & $52.5 \pm 32.7$ \\
\hline & Tokyo & $24.6 \pm 11.3$ & $22.5 \pm 7.4$ & $16.7 \pm 6.7$ & $25.9 \pm 7.5$ & $25.9 \pm 15.9$ & $21.2 \pm 7.6$ & $16.7 \pm 3.6$ & $24.6 \pm 7.2$ \\
\hline & Delhi & $200.1 \pm 115.6$ & $54.7 \pm 19.4$ & $22.6 \pm 11.6$ & $34.2 \pm 13.0$ & $179.8 \pm 123.3$ & $30.4 \pm 18.5$ & $13.3 \pm 4.2$ & $29.5 \pm 19.5$ \\
\hline \multirow[t]{6}{*}{ America } & Mexico City & $45.7 \pm 25.8$ & $37.7 \pm 19.9$ & $9.3 \pm 14.8$ & $55.3 \pm 43.6$ & $40.3 \pm 17.6$ & $29.3 \pm 18.4$ & $8.2 \pm 13.0$ & $51.7 \pm 40.2$ \\
\hline & New York & $13.0 \pm 7.5$ & $61.1 \pm 23.8$ & $1.1 \pm 1.2$ & $79.5 \pm 23.9$ & $13.5 \pm 5.9$ & $51.7 \pm 22.0$ & $1.1 \pm 0.9$ & $78.7 \pm 23.0$ \\
\hline & Los Angles & $25.6 \pm 12.6$ & $59.8 \pm 21.9$ & $0.9 \pm 0.6$ & $78.9 \pm 22.5$ & $27.3 \pm 10.5$ & $51.3 \pm 21.7$ & $0.9 \pm 0.5$ & $74.2 \pm 23.9$ \\
\hline & Quito & $44.2 \pm 29.7$ & $19.2 \pm 9.5$ & $2.0 \pm 1.2$ & $22.1 \pm 14.7$ & $37.0 \pm 25.9$ & $16.7 \pm 10.5$ & $2.4 \pm 2.1$ & $25.8 \pm 16.4$ \\
\hline & Sao Paulo & $21.6 \pm 9.6$ & $6.7 \pm 3.3$ & $15.0 \pm 10.2$ & $11.4 \pm 9.8$ & $18.8 \pm 7.8$ & $6.4 \pm 3.4$ & $14.6 \pm 11.9$ & $11.7 \pm 8.1$ \\
\hline & Santiago & $78.0 \pm 31.4$ & $80.6 \pm 31.4$ & $58.1 \pm 16.5$ & $25.4 \pm 11.5$ & $71.1 \pm 19.7$ & $85.4 \pm 33.4$ & $46.1 \pm 19.3$ & $29.9 \pm 11.5$ \\
\hline Africa & Johannesburg & $44.2 \pm 29.7$ & $32.8 \pm 20.4$ & $10.9 \pm 11.1$ & $37.0 \pm 24.2$ & $40.8 \pm 29.6$ & $28.2 \pm 16.7$ & $9.2 \pm 10.3$ & $33.9 \pm 21.0$ \\
\hline
\end{tabular}

Kerimray et al. 2020) due to the much-restricted mobility measures.

Additionally, the reduction in $\mathrm{SO}_{2}$ levels was caused by the reduced electricity consumption due to the restrictions of commercial, industrial activities (Anil and Alagha 2021, 2020; Awasthi et al. 2020; Broomandi et al. 2020; Rajput et al. 2020) (Tables 3-4 and Figure 3). The reduction in gas consumption and sharp reduction in international and domestic air traffic have also an important role in the reduction of the $\mathrm{SO}_{2}$ levels around the world (Biswas et al. 2020; Filonchyk and Peterson 2020; Pei et al. 2021). Regarding $\mathrm{O}_{3}$, as a secondary pollutant, due to the NOx-sensitive regime, the observed reduction in NOx emissions would cause an increase in $\mathrm{O}_{3}$ levels under a potential VOC-sensitive regime (Tables 3-4 and Figure 4) (Broomandi et al. 2020; Casado-Aranda et al. 2021; Kaskaoutis et al. 2021; Kerimray et al. 2020; Kumari and Toshniwal 2020; Lian et al. 2020; Lokhandwala and Gautam 2020).

The changes in the emissions of both primary or/and secondary particles can reduce particulate matter content. The primary PM refers to natural and anthropogenic activities such as wind erosion and road traffic in urban areas (Dumka et al. 2021; Kerimray et al. 2020; Pei et al. 2020; Srivastava et al. 2021), while the two main secondary PM components are nitrate and sulfate, formed in the air from precursors of $\mathrm{NO}_{2}$ and $\mathrm{SO}_{2}$. As a result, the reduction in the emissions of $\mathrm{NO}_{2}$ and $\mathrm{SO}_{2}$ could indirectly reduce the secondary ambient $\mathrm{PM}$ formation (Tables 3-4 and Figure 5).

\section{The effect of metrology}

It is necessary to assess the impact of weather conditions on the air quality since the concentrations of pollutants significantly depend not only on emissions but also on meteorological parameters, atmospheric chemistry, transport, and deposition (wet and/or dry). Figures 6-9 present the meteorological condition over studied cities in 2019 and 2020. A global reduction in Planetary Boundary Layer Height (PBLH) was observed in 2020 compared to 2019 (Figure 6), excluding South America, which had almost the same values in 2020 relative to 2019. The reduced PBLH was associated with a nearly decreased amount of precipitation in 2020 compared to 
Table 4 Percentage (\%) change in the concentrations of $\mathrm{PM}_{10}, \mathrm{NO}_{2}$, $\mathrm{SO}_{2}$, and ground-level $\mathrm{O}_{3}$ during the COVID-19 period in 2020 compared to the average of 2019 single year in 24 major cities in the world

\begin{tabular}{|c|c|c|c|c|c|}
\hline & City & $\mathrm{PM}_{10}(\%)$ & $\mathrm{NO}_{2}(\%)$ & $\mathrm{SO}_{2}(\%)$ & $\mathrm{O}_{3}(\%)$ \\
\hline \multirow[t]{8}{*}{ Europe } & Amsterdam & -9.02 & -16.43 & -21.39 & 8.17 \\
\hline & Berlin & -4.17 & -13.30 & 27.86 & -2.62 \\
\hline & Moscow & -73.91 & -66.11 & -34.77 & 6.02 \\
\hline & Paris & -28.70 & -86.57 & 11.89 & 21.14 \\
\hline & Rome & 2.95 & -21.67 & -5.97 & 0.63 \\
\hline & Warsaw & -9.15 & -3.30 & 15.32 & -21.69 \\
\hline & London & -10.06 & -34.99 & 59.97 & 15.11 \\
\hline & Madrid & -8.94 & -45.35 & -14.40 & 1.47 \\
\hline \multirow[t]{9}{*}{ Asia } & Tehran & -10.70 & -8.12 & 56.23 & 33.11 \\
\hline & Beijing & -7.27 & -20.42 & -41.27 & -3.22 \\
\hline & Istanbul & -28.82 & -20.67 & -24.07 & -17.57 \\
\hline & Almaty & -6.74 & 3.42 & -77.45 & NA \\
\hline & Turkestan & -36.48 & -15.96 & -187.74 & NA \\
\hline & Tel Aviv & -29.66 & -29.88 & 38.66 & 5.33 \\
\hline & Seoul & 0.51 & -28.65 & -12.55 & -3.90 \\
\hline & Tokyo & 5.21 & -6.37 & -64.67 & -5.21 \\
\hline & Delhi & -11.31 & -79.68 & -69.84 & -15.68 \\
\hline \multirow[t]{6}{*}{ America } & Mexico City & -13.33 & -28.77 & -12.99 & -6.97 \\
\hline & New York & 3.27 & -17.65 & -7.47 & -0.98 \\
\hline & Los Angles & 6.34 & -16.36 & -106.37 & -5.46 \\
\hline & Quito & -19.53 & -15.03 & 16.93 & 14.29 \\
\hline & Sao Paulo & -14.62 & -4.01 & -2.87 & 1.96 \\
\hline & Santiago & -9.74 & 5.66 & -26.05 & 15.00 \\
\hline Africa & Johannesburg & -8.21 & -17.00 & -18.89 & -9.52 \\
\hline
\end{tabular}

2019 (not in Seoul and Warsaw), which indicates an unfavorable weather condition to pollutant dispersion (Figure 7). This kind of unfavorable combination could intensify air pollution in a typical business-as-usual case, while the positive influence of the movement restrictions around the world seems to improve the air quality (Broomandi et al. 2020; Kerimray et al. 2020; Sharma et al. 2020; Xu et al. 2020). Figures 8 and 9 show similar patterns in the wind speed and wind direction during 2019 and 2020. Minor improvements in the air quality were observed in China due to unfavorable meteorology (Wang and $\mathrm{Su}$ 2020). Other studies confirmed the presence of favorable weather conditions to pollutant dispersion both before and during the lockdown in São Paulo, Brazil, indicating its positive effect on the top of lockdown effect on air quality improvement, which could be probably due to its coastal wind patterns (Biswas et al. 2020; Filonchyk and Peterson 2020; Nakada and Urban 2020). It is worth mentioning that air quality can be impacted due to trans-boundary transport of air pollutants from neighboring countries by prevailing winds. For example, in Eastern Asia, the predominant winds are from west to east and since Japan and South Korea are in the east of China, the air quality in both South Korea and Japan is altered by the air pollutants generated in Chinese industrial areas due to natural occurring Asian dust storms and coal-fired power generation. As a result, the introduced mobility restrictions in China from January 2020 to April 2020 (partially and/or fully) could also positively influence the air quality in Japan and South Korea as well as introduced preventive measures in both countries (Fu et al. 2020; Kim 2019; Nakata et al. 2015).

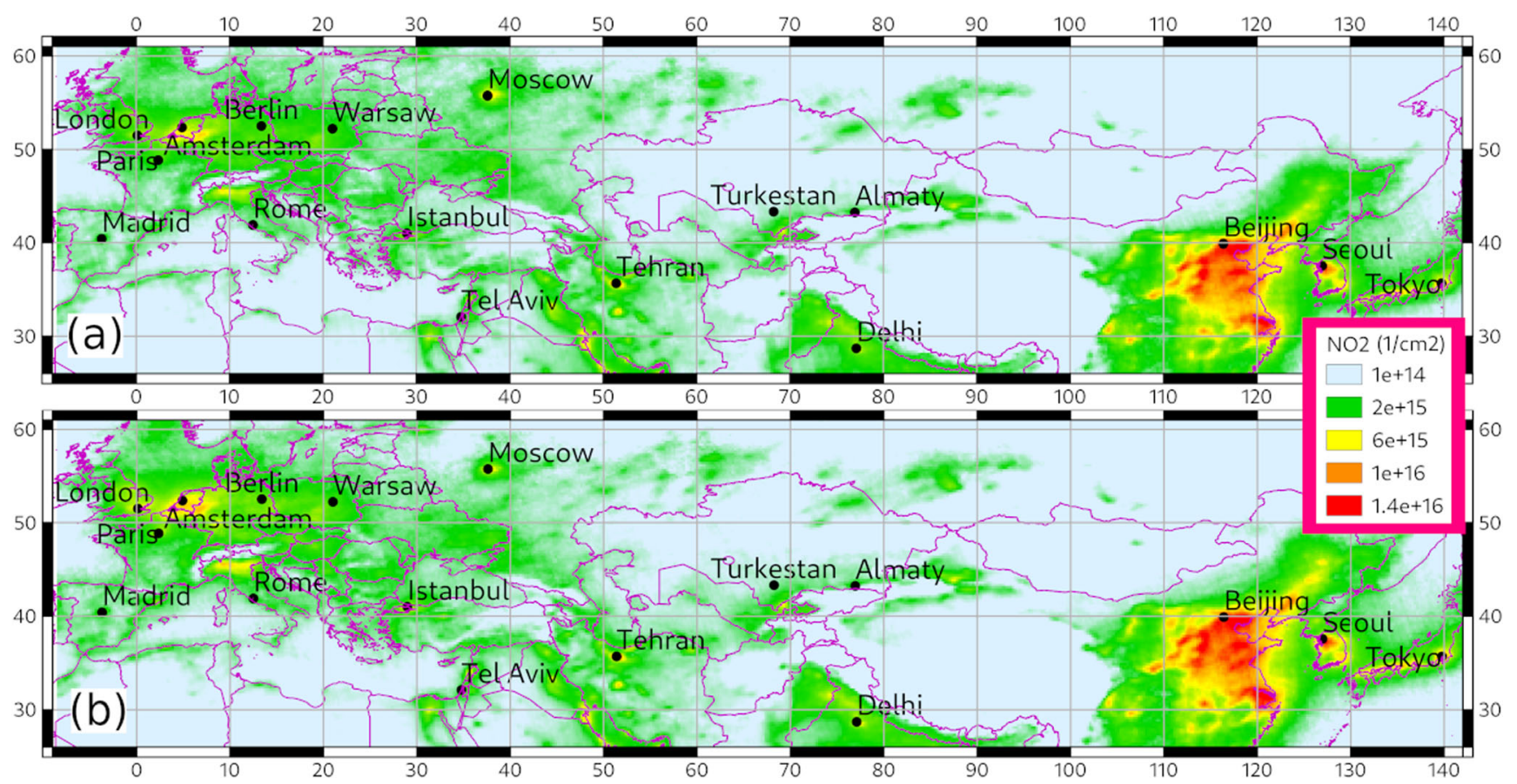

Figure 2 The average annual value of $\mathrm{NO}_{2}\left(1 / \mathrm{cm}^{2}\right)$ over Asia and Europe in a 2020 and $\mathbf{b} 2019$ 


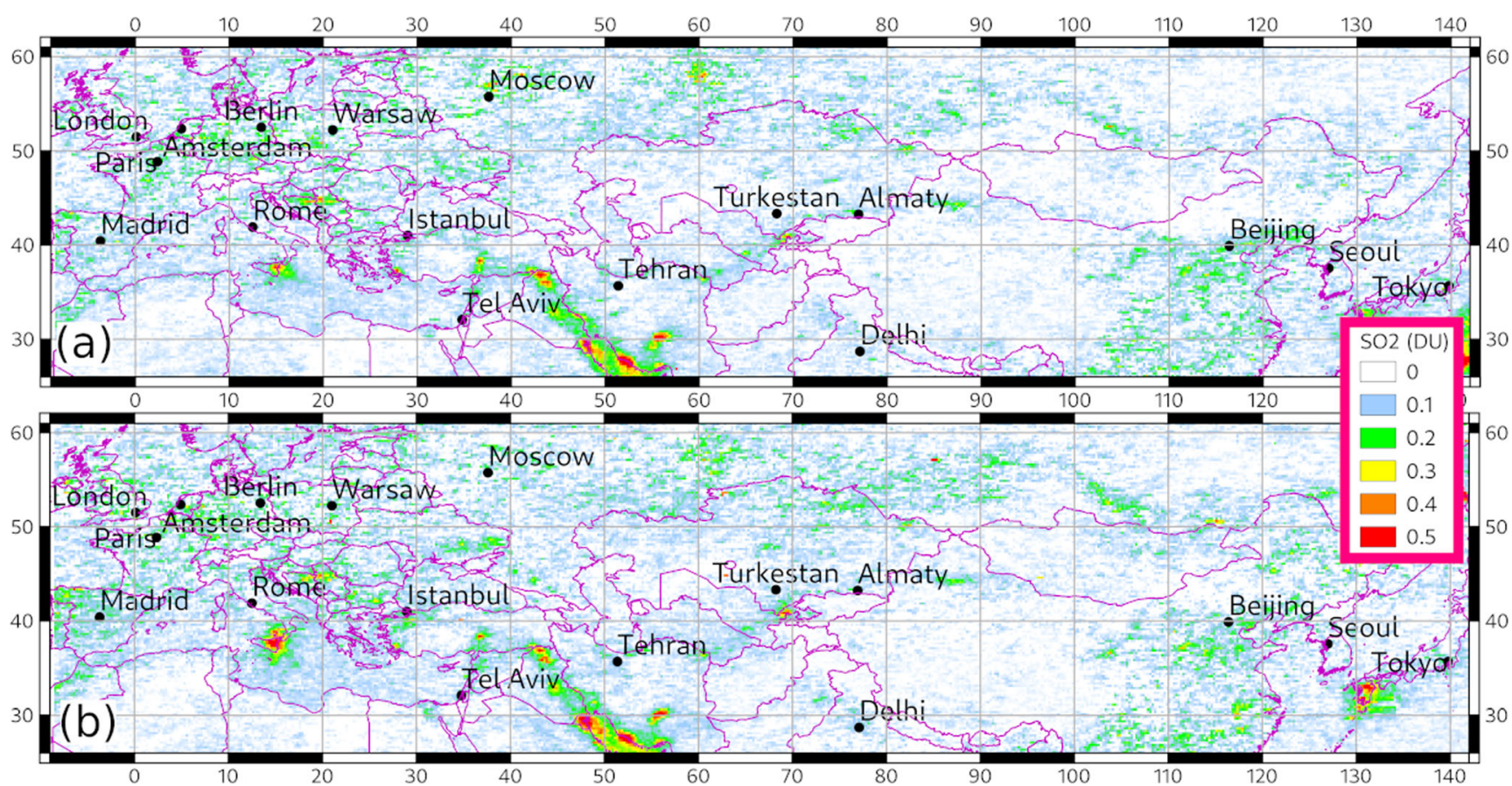

Figure 3 The average annual value of $\mathrm{SO}_{2}$ (DU) over Asia and Europe in a 2020 and b 2019

\section{Susceptibility of cultural heritage sites using dose- response functions}

To evaluate the possible impact of COVID-19 mobility restrictions on the susceptibility of cultural heritages to air pollution, dose-response functions were used in the current study to estimate the corrosion attack values in 24 cities worldwide for 2019 and 2020 (Figure 1). Figures 9-10 show the corrosion attack values for portland limestone, sandstone, copper, cast bronze, carbon steel, and zinc.

Table 5 suggests adopted target values to protect cultural heritage monuments and infrastructure materials by ICP Materials as a multiple $(n)$ of the background degradation rate. These values are set at $n=2$ for 2050 and $n=2.5$ for the year 2020 (CLRTAP 2014; ECE 2009; Spezzano 2021).

Table 6 shows the analysis of the Pearson correlation coefficients between surface recession and/or mass loss rates of

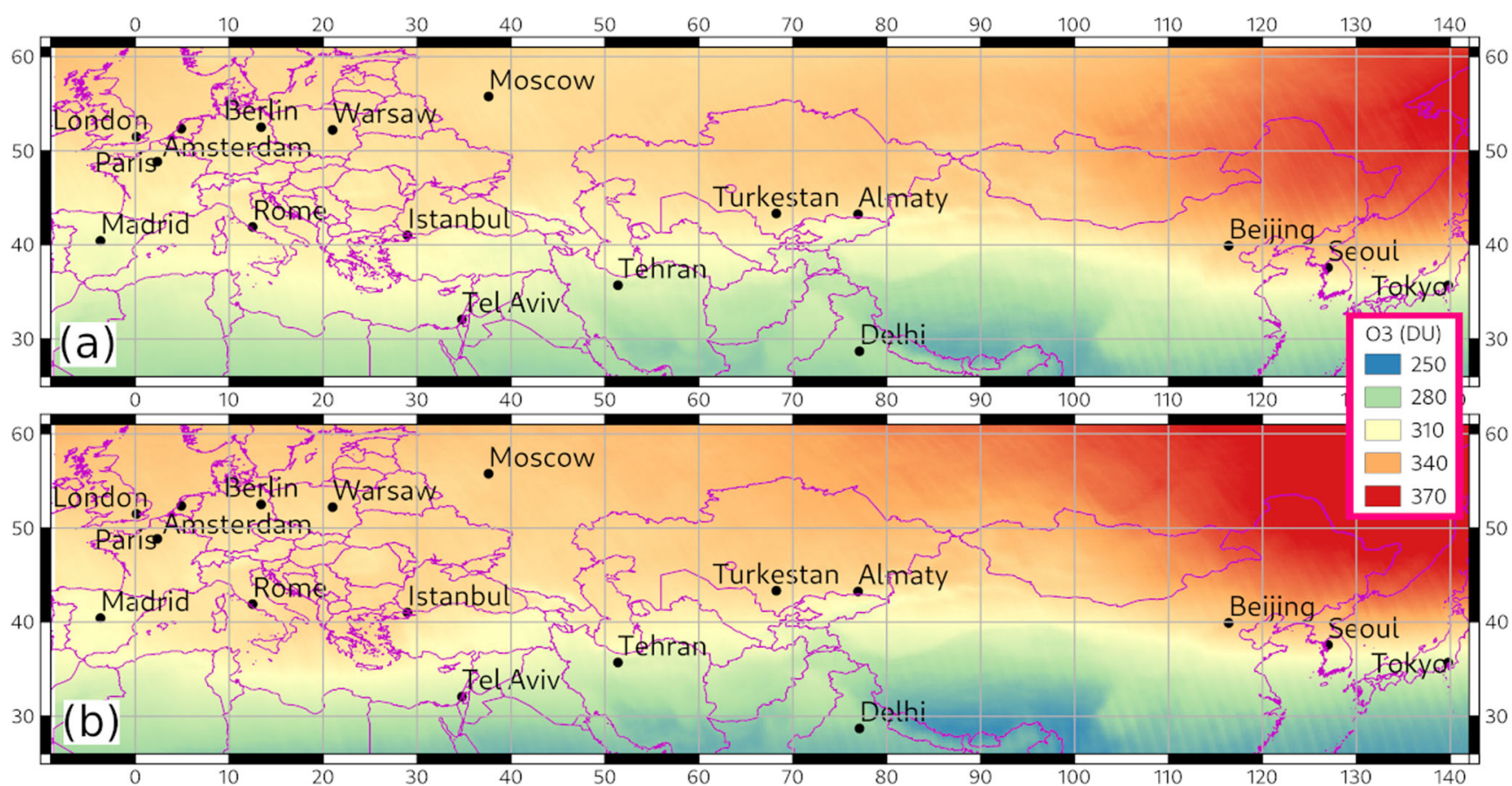

Figure 4 The average annual value of $\mathrm{O}_{3}$ (DU) over Asia and Europe in a 2020 and b 2019 


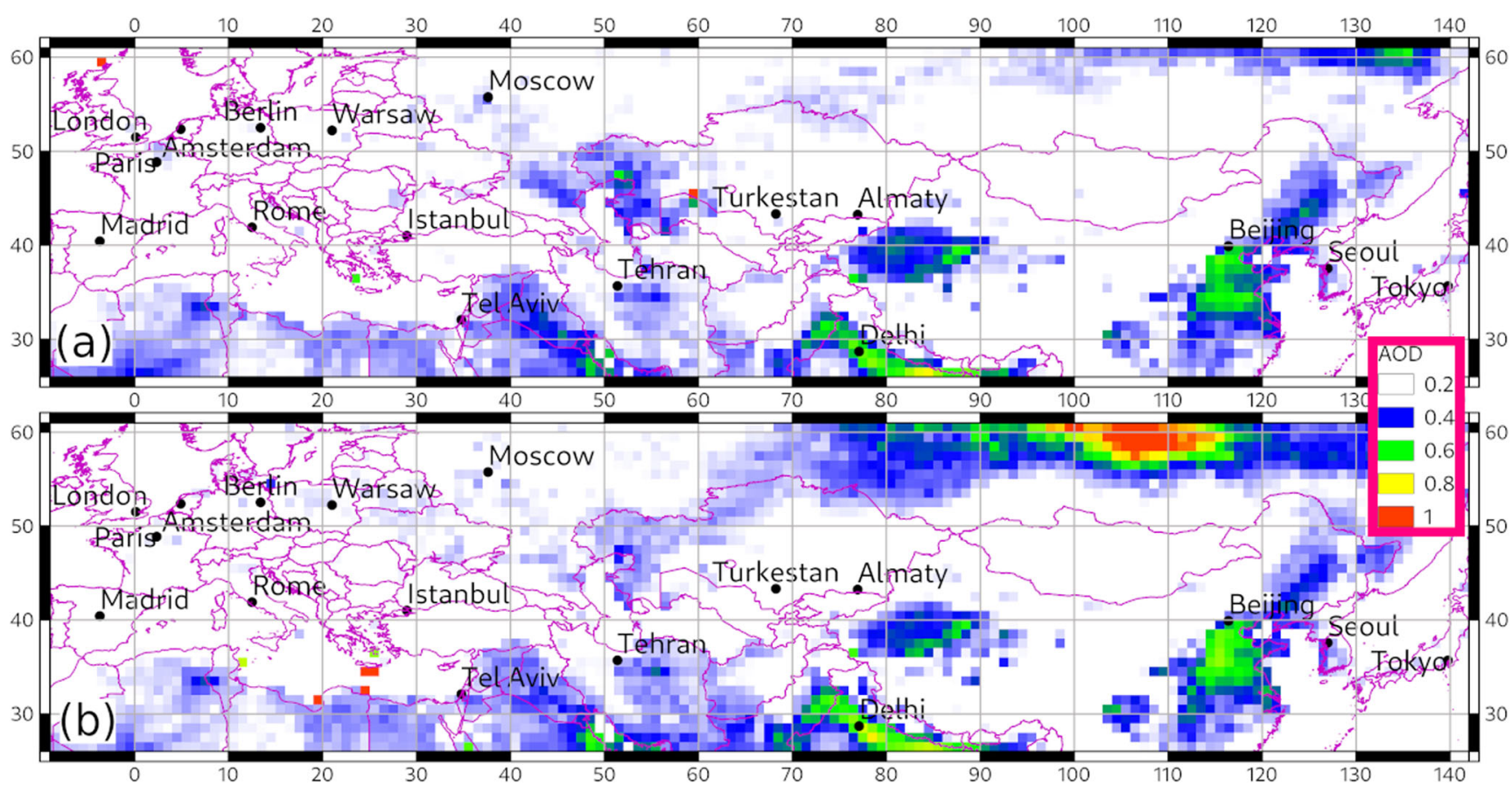

Figure 5 The average annual value of AOD over Asia and Europe in a 2020 and b 2019

portland limestone, sandstone, copper, cast bronze, carbon steel, and zinc and the annual average of pollutants $\left(\mathrm{SO}_{2}, \mathrm{NO}_{2}, \mathrm{HNO}_{3}\right.$, $\mathrm{O}_{3}, \mathrm{PM}_{10}, \mathrm{pH}$ ) and meteorological parameters (temperature, rainfall, relative humidity) in studied cities for 2019 and 2020.

The corrosion values for portland, cast bronze, and carbon steel were strongly correlated with $\mathrm{PM}_{10}$ concentration with correlation values of $+0.81,+0.98$, and +0.78 , respectively. There was also a strong positive correlation between sandstone corrosion rate and $\mathrm{SO}_{2}$ concentration $(+0.95)$ and between zinc corrosion rate and $\mathrm{HNO}_{3}$ concentration $(+0.88)$. At the same time, a negative correlation was observed between carbon steel corrosion rate and $\mathrm{O}_{3}$ concentration $(-0.35)$.

\section{Portland limestone}

The estimated corrosion depth values for 2019 and 2020 in studied cities indicated that the limestone degradation rate was above the background level but not exceeding the tolerable level in

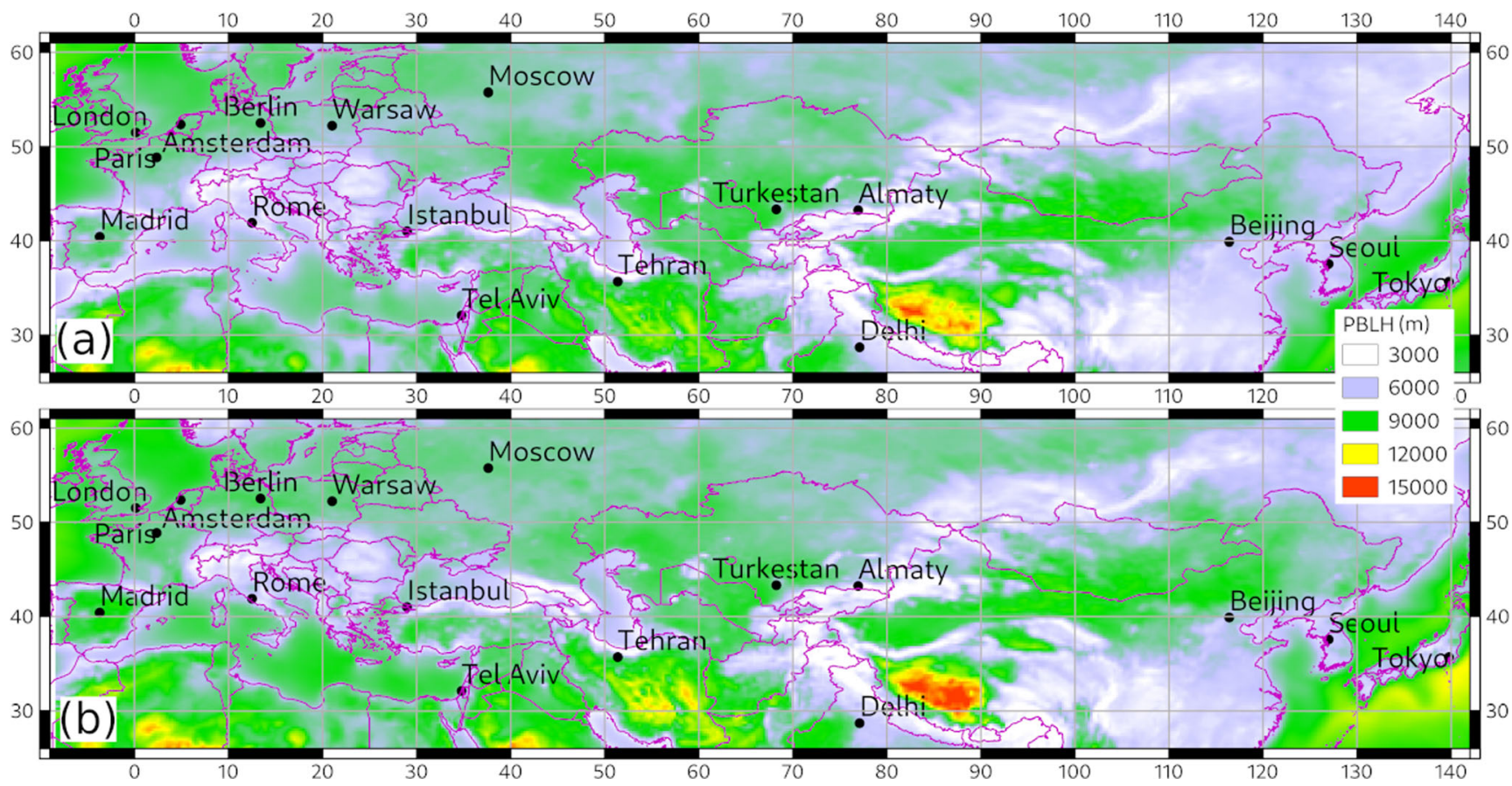

Figure 6 The average annual value of PBLH (m) over Asia and Europe in a 2020 and b 2019 


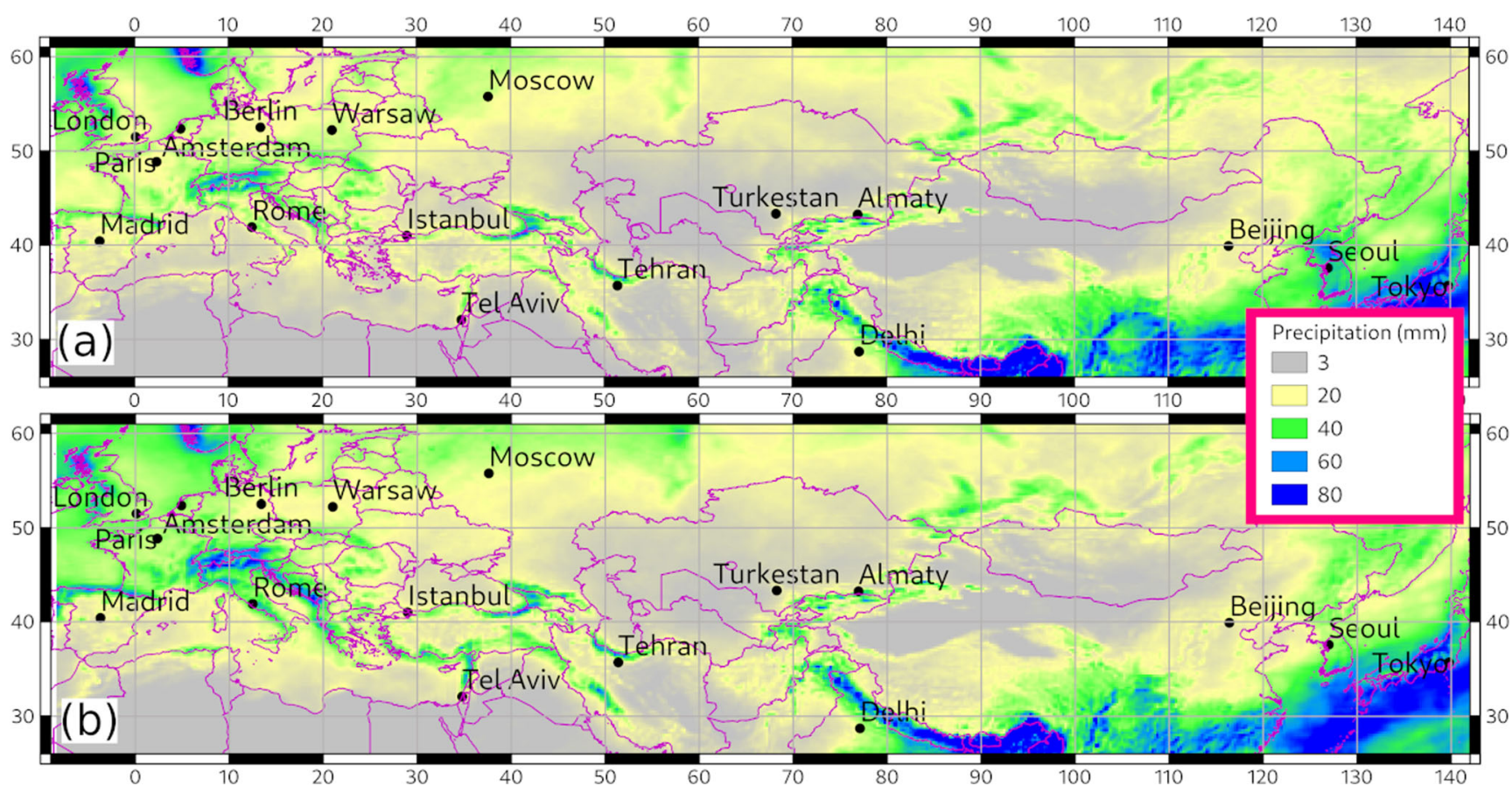

Figure 7 The average annual value of precipitation ( $\mathrm{mm}$ ) over Asia and Europe in a 2020 and b 2019

2020 except in Delhi, India (Figure 10A and Table 5). Compared to the tolerable rate in 2050 , it can be concluded that cultural heritages made of portland limestone might be under the degradation risk over New York (2019-2020), Istanbul (2019), Mexico City (2019), Tokyo (2020), and Santiago (2020). The improvements in air quality caused by mobility restrictions in Tokyo and Santiago, despite in other cities, mainly Istanbul and Mexico City, could not reduce the degradation risk in the cultural heritages made of limestone. The surface recession ranged between $4.6-11.3 \mu \mathrm{m}$ and $4.7-10 \mu \mathrm{m}$ in 2019 and 2020 , respectively. The highest percent of the reduction in degradation depth between 2019 and 2020 was observed in Mexico City by the value of $23.7 \%$, while the minimum percent was in Rome $(-0.30 \%)$. The surface recession increased in four cities with the highest percentage of $10 \%$ and $8.2 \%$ in Seoul and Santiago, respectively, in 2020 compared to 2019

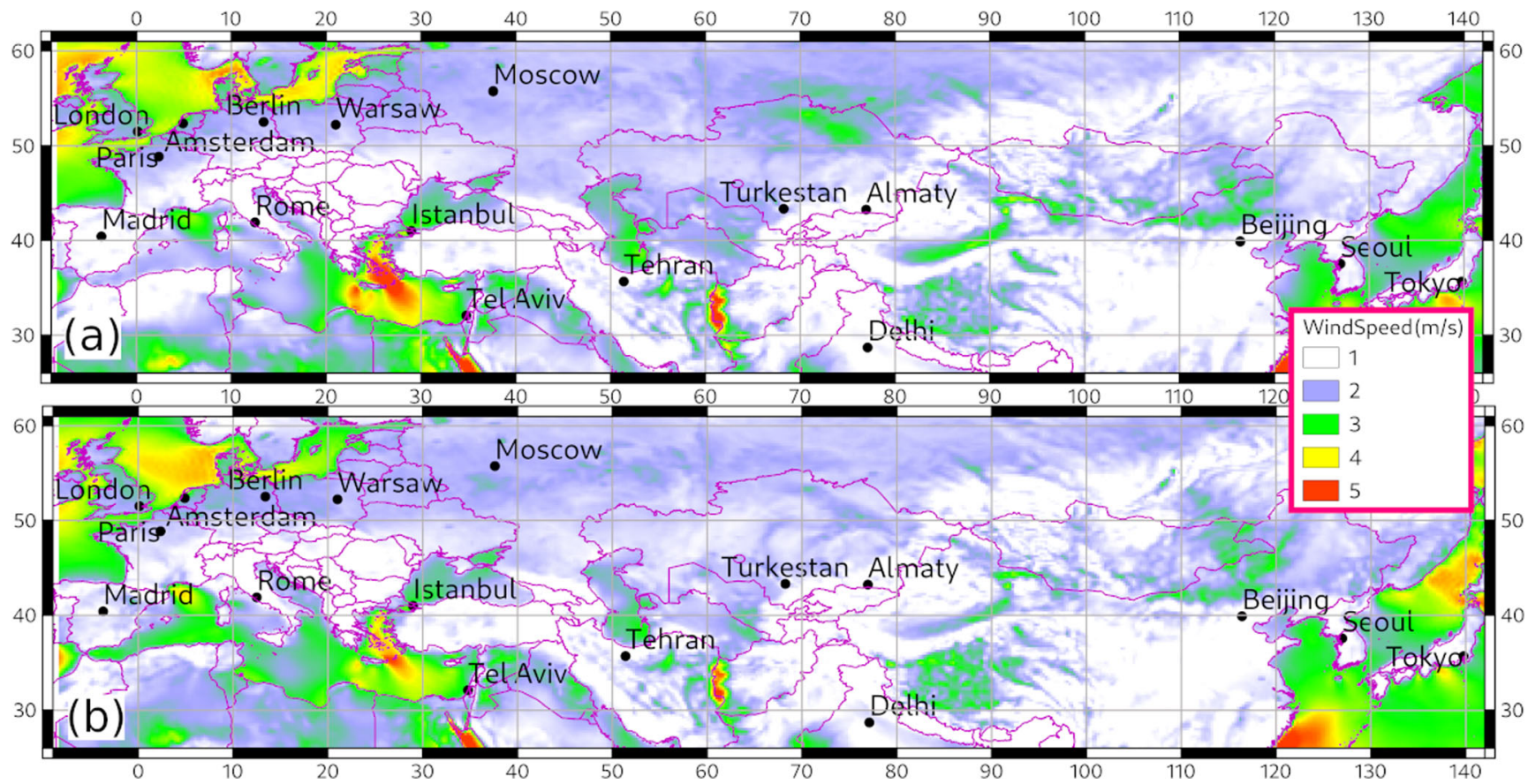

Figure 8 The average annual value of wind speed (m/s) over Asia and Europe in a 2020 and b 2019 


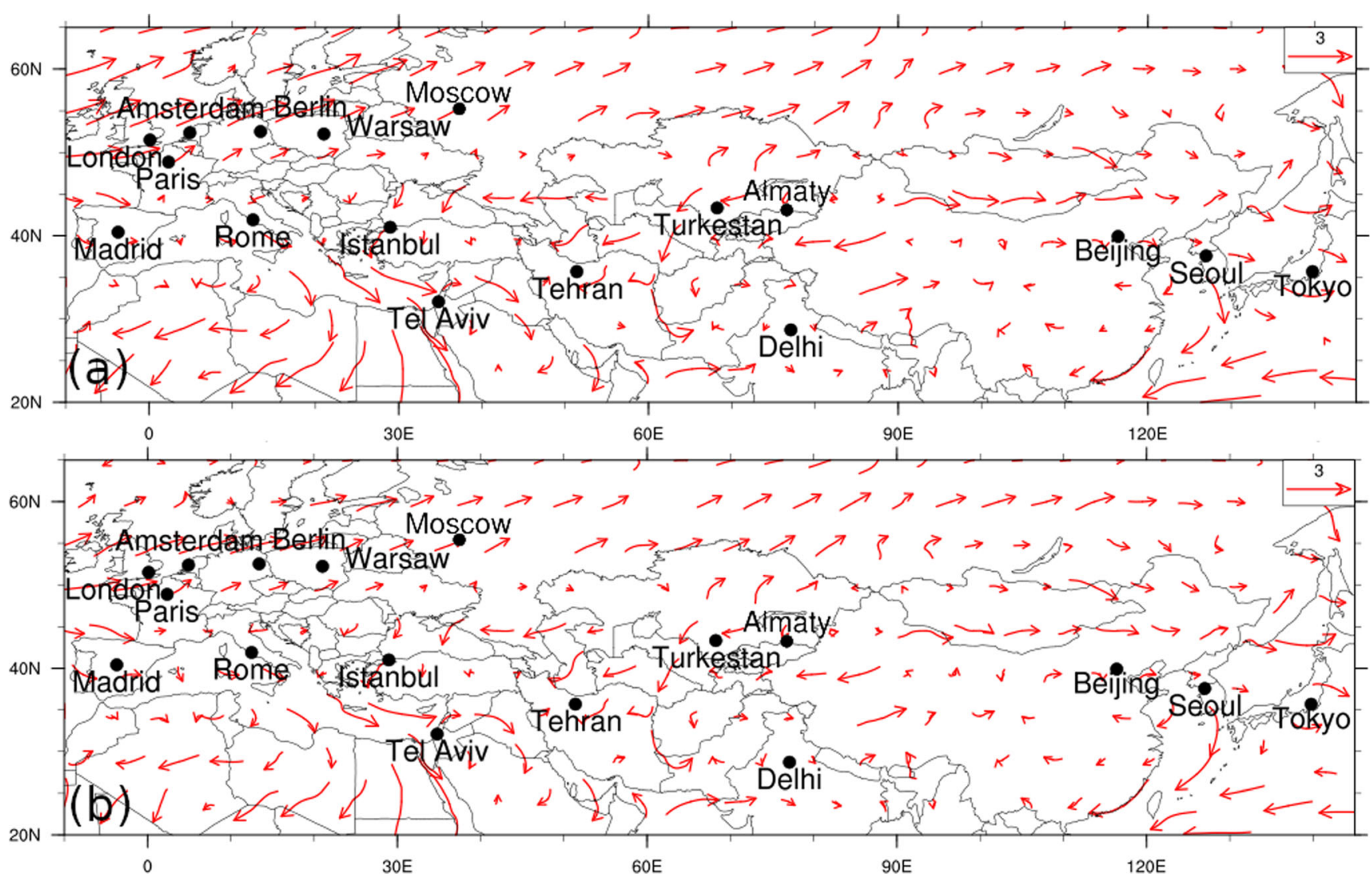

Figure 9 The average annual wind direction $\left(^{\circ}\right)$ over Asia and Europe in a 2020 and b 2019

(Figure 10A). The plausible reason behind the observed increase in degradation rate despite the reduction in air pollutants, mainly $\mathrm{PM}_{10}$ levels, could be attributed to the effect of meteorological parameters, including relative humidity and precipitation, on degradation attack values. ET analysis showed that the main influencing factor with a relative importance of 0.60 was $\mathrm{PM}_{10}$ (Figure 12A). Similar studies in Europe showed improvements in materials' conservation by investigating the reduction percent of cultural sites falling in the exceeding area for portland limestone (Di Turo et al. 2016). In 1998, the surface recession rates in Central Europe exceeded the value of $8 \mu \mathrm{m}$ and ranged from 5 to $6 \mu \mathrm{m}$ in France, Italy, and Spain. However, in 2000, the degradation values in Central Europe reached 5-6 $\mu \mathrm{m}$, while France and Spain remained under $4 \mu \mathrm{m}$. In Italy, the corrosion value did not decrease and stayed between 5 and $6 \mu \mathrm{m}$ in 2020 (Di Turo et al. 2016). In their study, the decline in $\mathrm{SO}_{2}$ and $\mathrm{PM}_{10}$ concentrations all over Europe (1980-2000) was responsible for reducing the limestone degradation rates (Di Turo et al. 2016).

\section{Sandstone}

The surface recession ranged between 1.5-25.30 $\mu \mathrm{m}$ and 1.5$19 \mu \mathrm{m}$ in 2019 and 2020, respectively. In both 2019 and 2020, the background level of sandstone's degradation rate was not exceeded in the cities of Amsterdam, Los Angles, New York, Paris, Rome, Quito, and Tel Aviv (Figure 10B and Table 5). The sandstone recession rate in 4 and 7 cities was above the suggested tolerable threshold in $2020(7.0 \mu \mathrm{m})$ and $2050(5.5 \mu \mathrm{m})$, respectively. The maximum reductions in degradation attack values were observed in Turkestan $(-43.0 \%)$ and Almaty $(-25.0 \%)$. On the other hand, the degradation depth increased in London and Tehran by $59.0 \%$ and $58.0 \%$, respectively. COVID-19 lockdowns in Turkestan, Delhi, and Seoul by notable reductions in $\mathrm{SO}_{2}$ concentrations could help the degradation rates to stay below the tolerable rates in 2020, but in Tehran, despite the mobility restrictions, observed increase in $\mathrm{SO}_{2}$ lead to exceedance of both tolerable thresholds. ET analysis showed the critical role of $\mathrm{SO}_{2}$ as well as $\mathrm{H}^{+}$with the relative importance of 0.6 and 0.23 , respectively, in influencing the sandstone recession rate (Figure 12B). Over Europe, the sandstone surface recession rates are generally low (below $2 \mu \mathrm{m}$ ) due to the current low levels of atmospheric $\mathrm{SO}_{2}$ corresponding improvements in air quality (Spezzano 2021). In our covered European cities, Moscow and Madrid had relatively higher values than their neighbors (Spezzano 2021). However, in Asia and South America, it can be concluded that cultural heritages made of sandstone might be under the degradation risk with rates beyond target value in 2050 $(5.5 \mu \mathrm{m})$. It is worth mentioning that the currently available sandstone dose-response function is dominated by $\mathrm{SO}_{2}$ and does not consider the impact of other pollutants, including $\mathrm{PM}_{10}$, the acidity of precipitation, and $\mathrm{HNO}_{3}$, which have essential roles in sandstone corrosions (Spezzano 2021). 

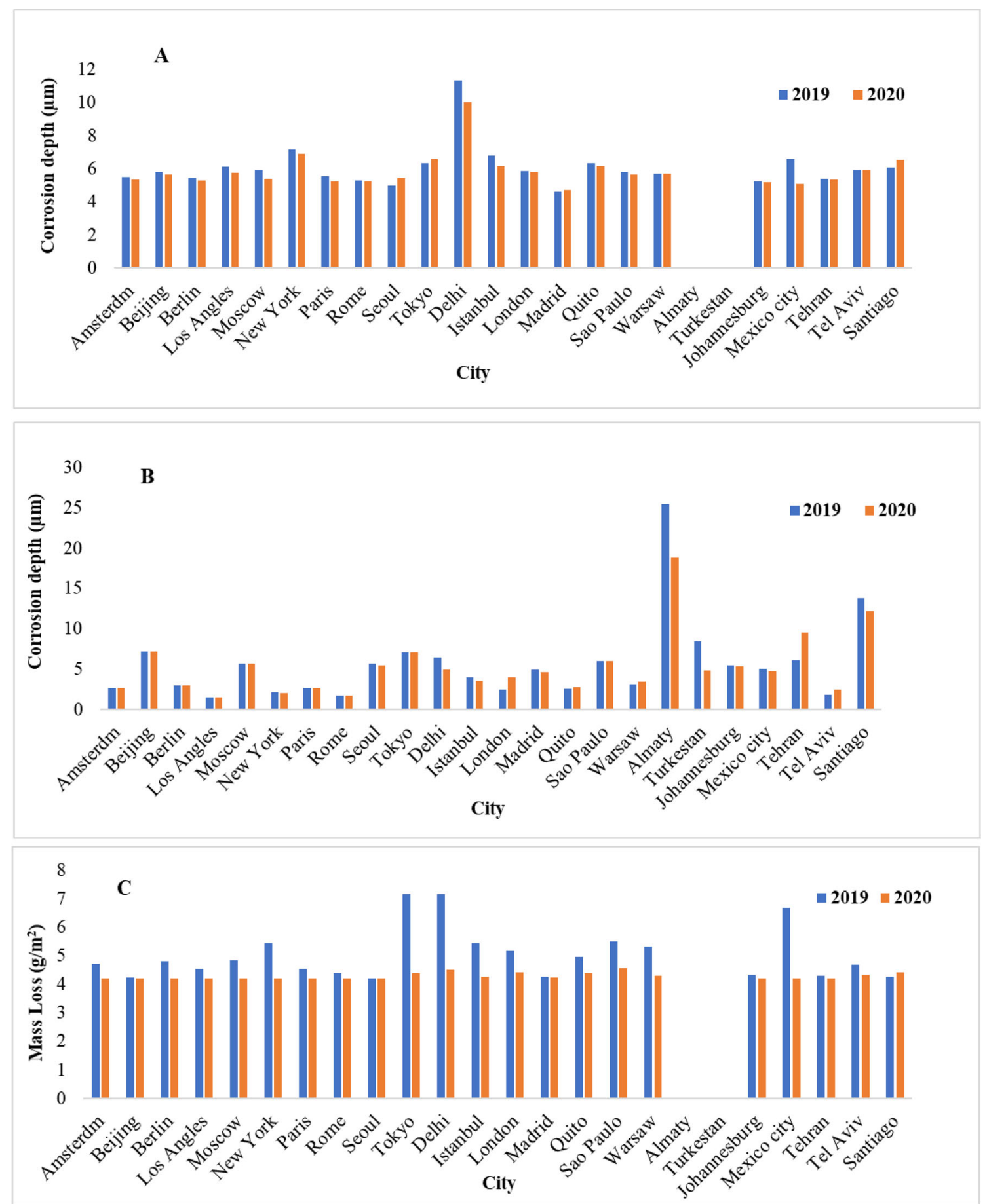

Figure 10 The comparison of the corrosion rate ( $\mu \mathrm{m}$ or $\mathrm{g} / \mathrm{m}^{3}$, first-year exposure) for A portland limestone, B sandstone, and C copper between 2019 and 2020 for the selected cities in the current study

\section{Copper}

Considering the cultural heritage building acceptable corrosion rate for copper in $2020\left(7 \mathrm{~g} / \mathrm{m}^{2}\right)$, there were three hotspots, Tokyo, Delhi, and Mexico City in 2019, while in
2020, none of the studied cities exceeded the target threshold for $2020\left(7 \mathrm{~g} / \mathrm{m}^{2}\right)$ and $2050\left(5.6 \mathrm{~g} / \mathrm{m}^{2}\right)$. There was a decreasing trend in surface recession rate for all studied cities, excluding Santiago, in 2020 relative to 2019 . The highest decreasing trend was observed in Tokyo, Mexico City, and Delhi, with 
Table 5 Tolerable degradation rate ( $\mu \mathrm{m}, 1$ st-year exposure)

\begin{tabular}{llll}
\hline Material & Background $(n=1)$ & Year 2050 $(n=2.0)$ & Year 2020 $(n=2.5)$ \\
\hline Limestone & 3.2 & 6.4 & 8 \\
Sandstone & 2.8 & 5.5 & 7 \\
Copper* & 0.32 & 0.64 & 0.8 \\
Bronze & 0.25 & 0.5 & 0.6 \\
Zinc & 0.45 & 0.9 & 1.1 \\
Carbon steel & 8.5 & 19 & 20 \\
\hline
\end{tabular}

*The tolerable degradation rates $\left(\mathrm{g} / \mathrm{m}^{2}\right)$ for mass loss are 7.0 and $5.6 \mathrm{~g} / \mathrm{m}^{2}$ for 2020 and 2050 , respectively values of $39.0 \%, 37.20 \%$, and $37.0 \%$, respectively (Figure 10C and Table 5).

ET analysis showed the important role of $\mathrm{PM}_{10}$ as well as rainfall with the relative importance of 0.32 and 0.20 , respectively, in influencing the copper mass loss rate (Figure 12C). The changes in $\mathrm{PM}_{10}$ as the main contributor in altering the copper corrosion risk under prevailing weather conditions due to the COVID-19 restrictions could mainly decrease the mass loss (Karaca 2013). In earlier conducted studies over Europe, Northern Europe and the UK were in the high-risk areas by exceeding the $7.1 \mathrm{~g} / \mathrm{m}^{2}$ in 1980 ,

Table 6 The Pearson correlation coefficients between surface recession and/or mass loss rates of portland limestone, sandstone, copper, cast bronze, carbon steel, and zinc and the annual average of pollutants while the rest of Europe was in the copper corrosion ranging between 4.0 and $6.5 \mathrm{~g} / \mathrm{m}^{2}$ (Di Turo et al. 2016; Spezzano 2021). In 2000, due to the air quality improvements across Europe, no more hotspots exceeding the limit value $\left(7.1 \mathrm{~g} / \mathrm{m}^{2}\right)$ were observed in Europe. Countries like the UK, France, Spain, and Portugal had corrosion levels below $4.0 \mathrm{~g} / \mathrm{m}^{2}$. The main contributor in copper mass loss estimation was rain $\mathrm{pH}$ all over Europe, but meteorological parameters as well as the presence of chloride ions also had their essential role in copper corrosion rate (Spezzano 2021). In 2017, the mass loss in Italy and Central Europe, being the host of

$\left(\mathrm{SO}_{2}, \mathrm{NO}_{2}, \mathrm{HNO}_{3}, \mathrm{O}_{3}, \mathrm{PM}_{10}, \mathrm{pH}\right)$ and meteorological parameters (temperature, rainfall, relative humidity) in studied cities for 2019 and 2020

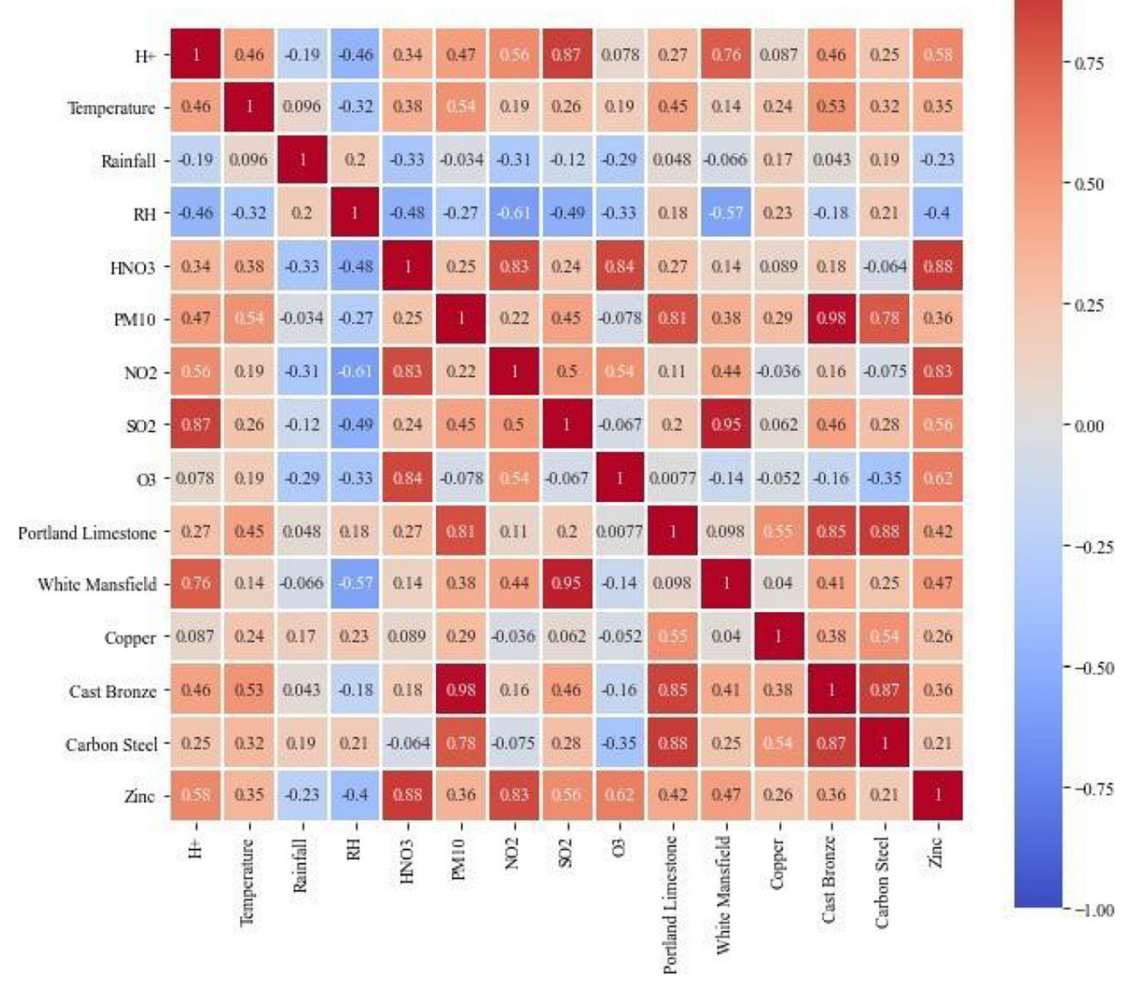




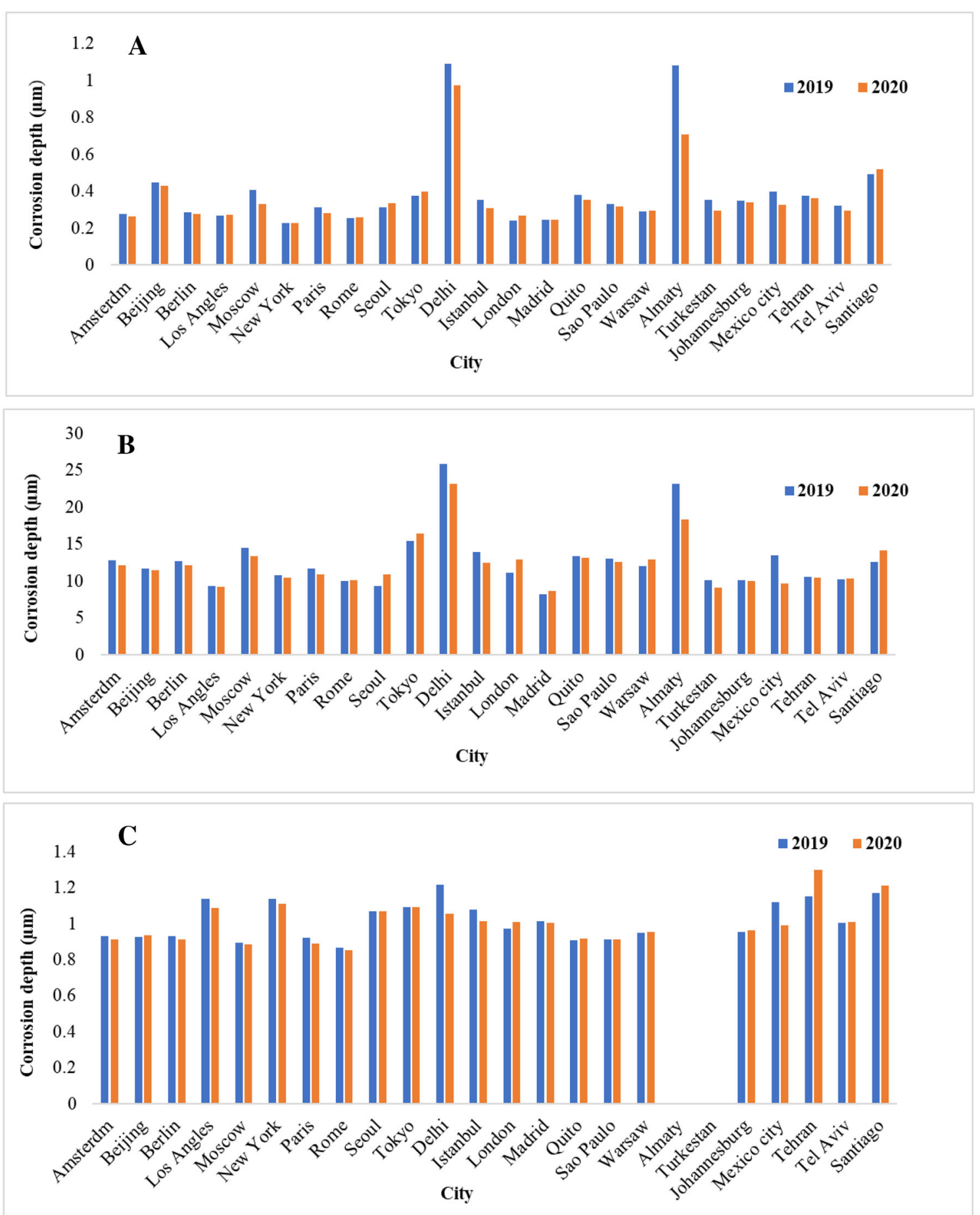

Figure 11 The comparison of the corrosion rate ( $\mu \mathrm{m}$, first-year exposure) for $\mathbf{A}$ cast bronze, $\mathbf{B}$ carbon steel, and $\mathbf{C}$ zinc between 2019 and 2020 for the selected cities in the current study

most UNESCO sites, ranged between 5.0 and $6.5 \mathrm{~g} / \mathrm{m}^{2}$ (Di Turo et al. 2016; Spezzano 2021). In Istanbul, by exceeding the tolerable copper rate of $0.8 \mu \mathrm{m}$ (target value in 2020), hotspots which are the host for cultural heritages such as the Hagia Irene, Sokollu Mehmet Pasha Mosque, Blue Mosque, Basilica Cistern and the Topkapi Palace, and Beyazit Mosque were under corrosion attack (Karaca 2013).

\section{Cast bronze}

The corrosion rate for cast bronze ranged between 0.23 to $1.1 \mu \mathrm{m}$ and 0.23 to $0.97 \mu \mathrm{m}$ in 2019 and 2020, respectively. In both 2019 and 2020, the background level of the cast bronze degradation rate was exceeded but not in the cities of New York and Madrid (Figure 11A and Table 5). The estimated values were below the cultural heritage building 


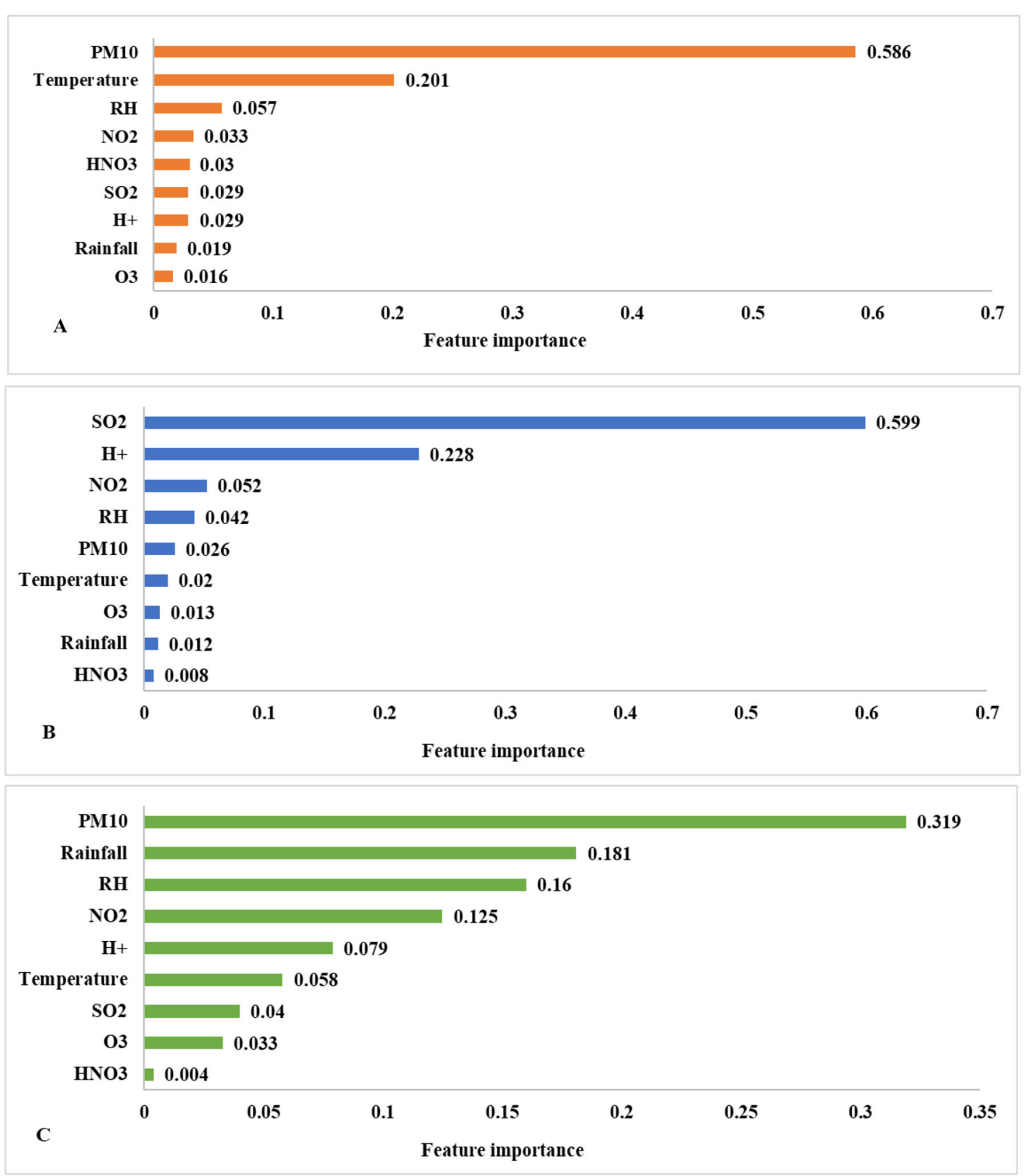

Figure 12 The feature importance plot using ET, the corrosion rate ( $\mu \mathrm{m}$ or $\mathrm{g} / \mathrm{m}^{3}$, first-year exposure) for A portland limestone, B sandstone, C copper, D cast bronze, $\mathbf{E}$ carbon steel, and $\mathbf{F}$ zinc in 2019 and 2020 for the selected cities in the current study

acceptable corrosion rate for cast bronze in 2020 and 2050 but not in Delhi, Almaty, and Santiago. It is about two times higher than the tolerable corrosion threshold in Delhi and Almaty. The COVID-19 lockdown caused a decreasing trend in surface recession rate for most of the studied with the highest value of $-34.0 \%,-19.0 \%$, and $-18.0 \%$ in Mexico City, Moscow, and Almaty, respectively. At the same time, mobility restrictions could not help decreasing the attack rate in Los Angles, Seoul, Rome, Tokyo, London, Warsaw, and Santiago, with the highest increasing rate of $11.0 \%$ in London. Generally, the cultural heritages made of cast bronze might not be under the corrosion risk in our studied areas with rates below target values in 2020 and 2050. ET analysis showed the important role of $\mathrm{PM}_{10}$ the relative importance of 0.90 in influencing the cast bronze corrosion rate (Figure 12D).

In 2013, the study conducted by Karaca over Istanbul showed the same trend in cast bronze corrosion trend as copper representing high corrosion risk with an average value of $1.15 \mu \mathrm{m}$, four times higher than the tolerable level in 2020 (Karaca 2013). In 1980, other studies showed exceeding the tolerable corrosion value in the UK. It ranged from 0.38 to $0.41 \mu \mathrm{m}$ and 0.24 to $0.35 \mu \mathrm{m}$ in Central and North Europe and 

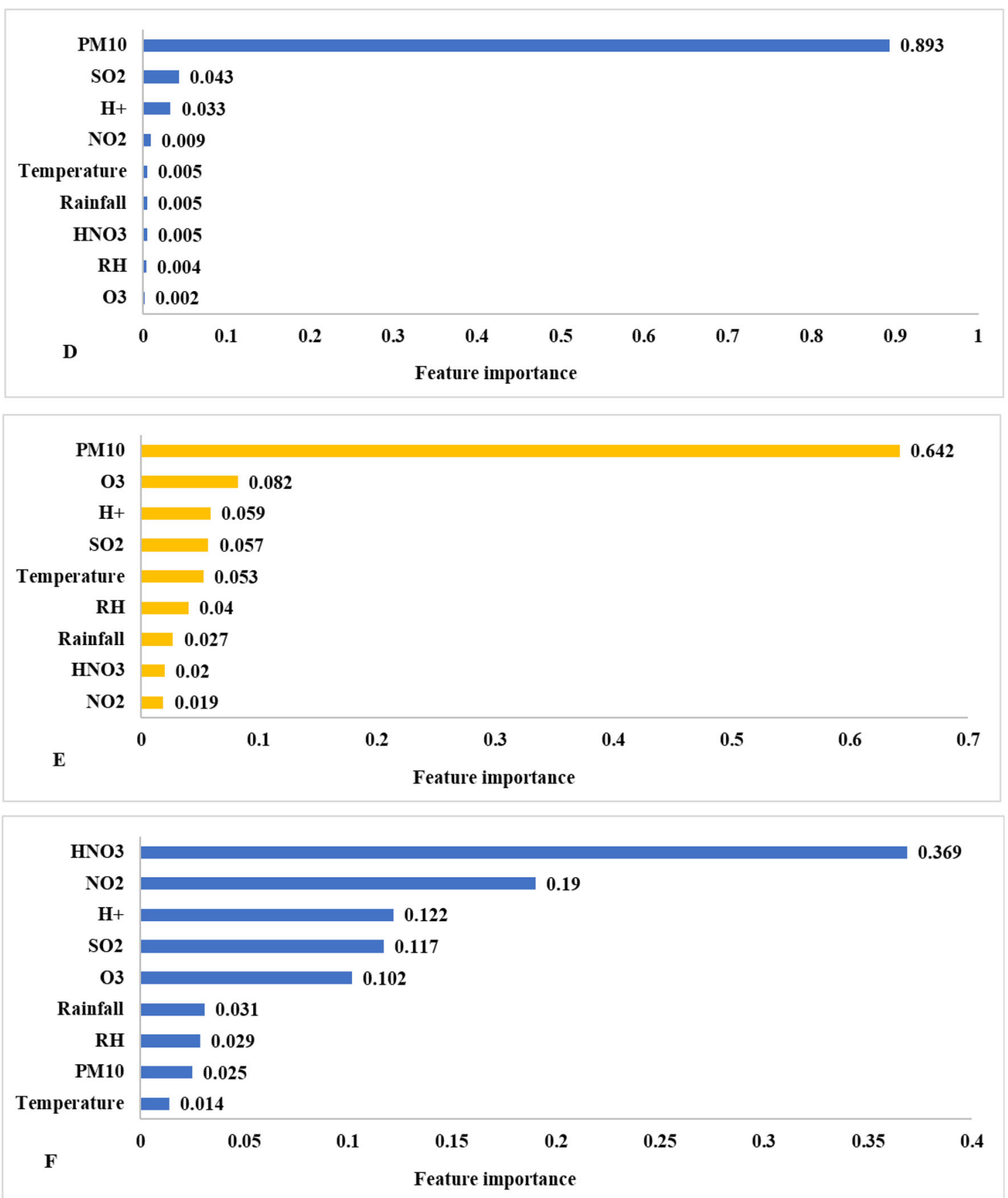

Fig. 12 (continued)

the rest of the European countries, respectively (Di Turo et al. 2016; Spezzano 2021). Based on their studies, the vast number of monuments fell in the corrosion levels between 0.24 and $0.35 \mu \mathrm{m}$. Additionally, the presence of chloride ions could also play an important role in metallic corrosion rate such as cast bronze. The deposition of chloride ions on the metallic surfaces can increase its corrosion rate. In the marine atmosphere, chloride ions are dominant which could probably cause greater metallic corrosion rates than expected in some coastal cities such as Istanbul (Alcántara et al. 2017; Ambler and Bain 1955).

On the other hand, with air quality improvements across Europe, the corrosion levels significantly reduced in 2000. The surface recession rate varied between 0.35 and $0.41 \mu \mathrm{m}$ in Italy and Central Europe. There were excellent results for material conservation in Spain, France, Portugal, the UK, and the Balkan area with corrosion value below $0.12 \mu \mathrm{m}$ (Spezzano 2021). In these studies, $\mathrm{PM}_{10}$ seems to be the main contributor 
to cast bronze corrosion in most of the studied areas over Europe. $\mathrm{SO}_{2}$ and rain acidity have an essential role in some hotspots located Scandinavian Peninsula (Spezzano 2021).

\section{Carbon steel}

Figure 11B shows the estimated surface recession rate values for 2019 and 2020 in studied cities, indicating that the carbon steel corrosion attack value was above the background level and exceeded the tolerable level in both 2020 and 2050, with the highest observed risk in Delhi and Almaty (Figure 11B and Table 5 ). The improvements in air quality caused by mobility restrictions in Seoul $(+17.0 \%)$, London $(+16.0 \%)$, and Santiago $(+13.0 \%)$ despite in Mexico City $(-29.0 \%)$, Almaty $(-21.0 \%)$, and Delhi $(-10 \%)$ could not reduce the corrosion risk in the cultural heritages made of carbon steel. The surface recession ranged between $8.5-26.0 \mu \mathrm{m}$ and 8.6-23.1 $\mu \mathrm{m}$ in 2019 and 2020, respectively. For both 2019 and 2020, the minimum value was estimated in Madrid, while the maximum was in Delhi. ET analysis showed the important role of $\mathrm{PM}_{10}$ the relative importance of 0.64 in influencing the carbon steel corrosion rate (Figure 12E).

In 2017, the carbon steel corrosion rate, first-year exposure, was not excessively high over Europe, ranging from 8 to $12 \mu \mathrm{m}$. However, some hotspots were observed exceeding the target value for $2020(20 \mu \mathrm{m})$ (Spezzano 2021). The general low rate of carbon steel corrosion was attributed to the reduction in $\mathrm{SO}_{\mathrm{x}}$ emissions by $90 \%$ in the European Union due to the wide range of environmental policy measures (Spezzano 2021). In their study, the rain acidity and $\mathrm{SO}_{2}$ had an essential role in influencing the carbon steel corrosion rate, while ambient $\mathrm{PM}_{10}$ level appears to have a minor role in the corrosion rate (Spezzano 2021). In Istanbul, the minimum calculated surface recession rate over the peninsula area was $28.9 \mu \mathrm{m}$, which was about $45 \%$ higher than the tolerable corrosion rate (which might be due to the salinity of its atmosphere), indicating that the area mentioned above was under serious carbon steel corrosion risk (Karaca 2013).

\section{Zinc}

The zinc surface recession ranged between $0.9-1.20 \mu \mathrm{m}$ and $0.85-1.30 \mu \mathrm{m}$ in 2019 and 2020, respectively. In both 2019 and 2020, the background level of zinc's degradation rate was exceeded by 2-3 times (Figure 12F and Table 5). In 2019, it was about 35\%,26\%,26\%,24\%, and 20\% higher than the target set for $2050(0.9 \mu \mathrm{m})$ in Delhi, Los Angeles, New York, Mexico City, and Istanbul, respectively, while the values were of $17 \%$, $21 \%, 23 \%, 10 \%$, and $13 \%$ for the cities mentioned above, respectively, indicating the impact of COVID-19 lockdown around the world in 2020. On the other hand, the corrosion rate changes (relative to 2050 target value) experienced an increase in Tehran and Santiago from $28 \%$ to $44 \%$ and $30 \%$ to $25 \%$, respectively, in 2020 relative to 2019 . The maximum reductions in corrosion attack values were observed in Delhi $(-13.0 \%)$ and Mexico City $(-11.0 \%)$. However, the corrosion depth increased in Tehran and Santiago by percentage of $13.0 \%$, and $4.0 \%$, respectively. ET analysis showed the important role of $\mathrm{HNO}_{3}$ and $\mathrm{NO}_{2}$ with the relative importance of 0.40 , and 0.20 , respectively, in influencing the zinc corrosion rate (Figure 12F).

Referring to previous studies, the estimated zinc corrosion rate was beyond the target value in 2050 in a vast part of Europe (Spezzano 2021). $\mathrm{HNO}_{3}$ level seems to be important and atmospheric $\mathrm{SO}_{2}$ in zinc corrosion rate in Central Europe, Greece, Italy, and Turkey. They also showed the significant influence of rain acidity on corrosion rate in Northern Europe's limited areas (Spezzano 2021).

\section{Conclusion}

In the current study, for the first time, available dose-response functions and environmental data were deployed to study the potential benefits of traffic and urban mobility reductions on the natural process of deterioration of materials during COVID-19 lockdown in twenty-four major cities on five continents. Despite the unfavorable global weather conditions, the considerable impact of COVID-19 mobility restrictions on air quality was found in 24 major cities worldwide, including significant decreases in the values of $\mathrm{PM}_{10}, \mathrm{NO}_{2}$, and $\mathrm{SO}_{2}$ and increases of ground-level $\mathrm{O}_{3}$ in 2020 compared to 2019 . The introduced mobility restrictions in 2020 could decrease the surface recession rate of portland, sandstone, copper, cast bronze, carbon steel, and zinc in most of the studied cities but in Santiago (portland, copper, cast bronze, carbon steel, and zinc), Seoul (portland, cast bronze, and carbon steel), Tehran (sandstone and zinc), London (sandstone, cast bronze, and carbon steel). Extremely randomized trees (ET) analysis showed that $\mathrm{PM}_{10}$ was the main influencing factor for corrosion of portland, copper, cast bronze, and carbon steel with a relative importance of $0.60,0.32,0.90$, and 0.64, respectively, while $\mathrm{SO}_{2}$ and $\mathrm{HNO}_{3}$ were mainly responsible for degradation of sandstone and zinc with a relative importance of 0.60 and 0.40 , respectively. Generally, the results indicate that, despite the considerable reduction in air pollution across the world in 2020, atmospheric pollution is still an essential and constant threat to cultural heritage and plays a vital role as an agent of deterioration of materials. As a result, a fair number of monuments are still exposed to a high level of ambient pollution, precisely in metropolitan areas, and consequently are vulnerable to corrosion and/or degradation requiring particular attention. The global pandemic lockdown clearly showed that it is possible to reduce air pollution in megacities and proximity of sensitive cultural buildings significantly by effective traffic control programs along with the promotions of green commuting and the technologies to expand remote working. 
Supplementary Information The online version contains supplementary material available at https://doi.org/10.1007/s11356-021-16078-5.

Acknowledgements The authors acknowledge financial support from Nazarbayev University faculty-development competitive research grants (FCDRGP) (Funder Project Reference: 280720FD1904).

Author contribution Parya Broomandi: Writing - original draft, conceptualization, methodology, validation, formal analysis, investigation, data curation

Aidana Tleuken: Writing — original draft, investigation

Shaikhislam Zhaxylykov: Conceptualizing, methodology, writingoriginal draft, investigation

Amirhossein Nikfal: Formal analysis, resources, data curation

Jong Ryeol Kim: Resources, data curation, funding acquisition

Ferhat Karaca: Supervision, conceptualization, methodology, validation, review and editing, project administration, funding acquisition.

Data availability Data is available on request from the corresponding author.

\section{Declarations}

Ethics approval Not applicable.

Consent to participate Not applicable.

Consent for publication Not applicable.

Conflict of interest The authors declare no competing interests.

\section{References}

Agostino D, Arnaboldi M, Lampis A (2020) Italian state museums during the COVID-19 crisis: from onsite closure to online openness. Museum Manag Curatorsh 35(4):362-372. https://doi.org/10.1080/ 09647775.2020.1790029

Alcántara J, Fuente D, Chico B et al (2017) Marine atmospheric corrosion of carbon steel: a review. Mater. (Basel, Switzerland) 10(4):406. https://doi.org/10.3390/ma10040406

Ambler HR, Bain AAJ (1955) Corrosion of metals in the tropics. J Appl Chem 5(9):437-467. https://doi.org/10.1002/jctb.5010050901

Anil I, Alagha O (2020) Source apportionment of ambient black carbon during the COVID-19 lockdown. Int J Environ Res Public Health 17(23):9021. https://doi.org/10.3390/ijerph17239021

Anil I, Alagha O (2021) The impact of COVID-19 lockdown on the air quality of Eastern Province. Saudi Arabia Air Qual Atmos Heal 14: 117-128. https://doi.org/10.1007/s11869-020-00918-3

Atkinson R (2020) How can digital platforms help museums connect to audiences during Covid-19 emergency? Museums Assoc.

Awasthi A, Sharma A, Kaur P, Gugamsetty B, Kumar A (2020) Statistical interpretation of environmental influencing parameters on COVID-19 during the lockdown in Delhi. India Environ Dev Sustain 25:1-14. https://doi.org/10.1007/s10668-020-01000-9

Aydın S, Nakiyingi BA, Esmen C, Güneysu S, Ejjada M (2020) Environmental impact of coronavirus (COVID-19) from Turkish perceptive. Environ Dev Sustain 23:7573-7580. https://doi.org/10. 1007/s10668-020-00933-5

Baltrènas P, Januševičius T, Chlebnikovas A (2017) Research into the impact of speed bumps on particulate matter air pollution. Meas J Int Meas Confed 100:62-67. https://doi.org/10.1016/j.measurement. 2016.12.042
Biswas K, Chatterjee A, Chakraborty J (2020) Comparison of air pollutants between Kolkata and Siliguri, India, and its relationship to temperature change. J Geovisualization Spat Anal 4(25). https:// doi.org/10.1007/s41651-020-00065-4

Bloom LB (2020) Ranked: the world's 15 best virtual tours to take during coronavirus. Forbes.com.

Brimblecombe P, Hayashi M, Futagami Y (2020) Mapping climate change, natural hazards and Tokyo's built heritage. Atmosphere (Basel) 11(7):680. https://doi.org/10.3390/atmos11070680

Broomandi P, Karaca F, Nikfal A, Jahanbakhshi A, Tamjidi M, Kim JR (2020) Impact of COVID-19 event on the air quality in Iran. Aerosol Air Qual Res 20:1793-1804. https://doi.org/10.4209/aaqr.2020.05. 0205

Casado-Aranda LA, Sánchez-Fernández J, Viedma-del-Jesús MI (2021) Analysis of the scientific production of the effect of COVID-19 on the environment: a bibliometric study. Environ Res 193:110416. https://doi.org/10.1016/j.envres.2020.110416

Chen Z, Hao X, Zhang X, Chen F (2021) Have traffic restrictions improved air quality? A shock from COVID-19. J Clean Prod 279: 123622. https://doi.org/10.1016/j.jclepro.2020.123622

CLRTAP (2014) Guidance on mapping concentrations levels and deposition levels, Chapter 4 of Manual on methodologies and criteria for modelling and mapping critical loads and levels and air pollution effects, risks and trends. UNECE Convention on Long-range Transboundar.

Comite V, Fermo P (2018) The effects of air pollution on cultural heritage: the case study of Santa Maria delle Grazie al Naviglio Grande (Milan). Eur Phys J Plus 133:556. https://doi.org/10.1140/epjp/ i2018-12365-6

Comite V, Pozo-antonio JS, Cardell C et al (2020) Environmental impact assessment on the Monza Cathedral (Italy): a multi-analytical approach 11: 291-304.

Di Turo F, Proietti C, Screpanti A et al (2016) Impacts of air pollution on cultural heritage corrosion at European level: what has been achieved and what are the future scenarios. Environ Pollut 218: 586-594. https://doi.org/10.1016/j.envpol.2016.07.042

Dumka UC, Kaskaoutis DG, Verma S, Ningombam SS, Kumar S, Ghosh S (2021) Silver linings in the dark clouds of COVID-19: improvement of air quality over India and Delhi metropolitan area from measurements and WRF-CHIMERE model simulations. Atmos Pollut Res 12:225-242. https://doi.org/10.1016/j.apr.2020.11.005

ECE (2009) Review of air pollution effects. Indicators and targets for air pollution effects. Report to the 28th Session of the Working Group on Effects, UN-ECE Convention on Long-range Transboundary Air Pollution, Working Group on Effects, Geneva, Switzerland ECE/E.

Federal Environmental Agency (2004) Manual on methodologies and criteria for modelling and mapping critical loads \& levels and air pollution effects, risks and trends. Federal Environmental Agency (Umweltbundesamt), Germany

Filonchyk M, Peterson M (2020) Air quality changes in Shanghai, China, and the surrounding urban agglomeration during the COVID-19 lockdown. J Geovisualization Spat Anal 4(22). https://doi.org/10. 1007/s41651-020-00064-5

Fu F, Purvis-Roberts KL, Williams B (2020) Impact of the COVID-19 pandemic lockdown on air pollution in 20 major cities around the world. Atmosphere (Basel). 11:1189. https://doi.org/10.3390/ atmos11111189

González Martínez P (2017) Built heritage conservation and contemporary urban development: the contribution of architectural practice to the challenges of modernisation. Built Herit 1:14-25. https://doi.org/ $10.1186 / \mathrm{bf} 03545666$

Gössling S, Scott D, Hall CM (2020) Pandemics, tourism and global change: a rapid assessment of COVID-19. J Sustain Tour 29:1-20. https://doi.org/10.1080/09669582.2020.1758708

Grant D (2020) Pandemic pushes museums deeper into digital Age. Wall Str. J. 
Hozo SP, Djulbegovic B, Hozo I (2005) Estimating the mean and variance from the median, range, and the size of a sample. BMC Med Res Methodol 5, 5(13). https://doi.org/10.1186/1471-2288-5-13

Ivaskova M, Kotes P, Brodnan M (2015) Air pollution as an important factor in construction materials deterioration in Slovak Republic. Procedia Eng 108:131-138. https://doi.org/10.1016/j.proeng.2015. 06.128

Jones D (2020) 12 virtual-reality tours to check out during the coronavirus outbreak - The Washington Post. Washington Post.

Karaca F (2013) Mapping the corrosion impact of air pollution on the historical peninsula of Istanbul. J Cult Herit 14:129-137. https://doi. org/10.1016/j.culher.2012.04.011

Kaskaoutis DG, Grivas G, Liakakou E (2021) Assessment of the COVID-19 lockdown effects on spectral aerosol scattering and absorption properties in Athens. Greece Atmos Basel 12(2):231. https://doi.org/10.3390/atmos12020231

Kerimray A, Baimatova N, Ibragimova OP, Bukenov B, Kenessov B, Plotitsyn P, Karaca F (2020) Assessing air quality changes in large cities during COVID-19 lockdowns: the impacts of traffic-free urban conditions in Almaty. Kazakhstan Sci Total Environ 730: 139179. https://doi.org/10.1016/j.scitotenv.2020.139179

Kim MJ (2019) The effects of transboundary air pollution from China on ambient air quality in South Korea. Heliyon 5:e02953. https://doi. org/10.1016/j.heliyon.2019.e02953

Kita I, Sato T, Kase Y, Mitropoulos P (2004) Neutral rains at Athens, Greece: a natural safeguard against acidification of rains. Sci Total Environ 327:285-294. https://doi.org/10.1016/j.scitotenv.2004.01. 012

Knotkova D, Kreislova K (2007) Atmospheric corrosion and conservation of copper and bronze. In: Environmental deterioration of materials. WIT Press, Ashurst Lodge, Southampton, UK, pp 107-142. https://doi.org/10.2495/978-1-84564-032-3/04

Kucera V (2005) MULTI-ASSESS. Model for multi-pollutant impact and assessment of threshold levels for cultural heritage. EU 5FP RTD project, contract number: EVK4- CT-2001-00044.

Kucera V, Fitz S (1995) Direct and indirect air pollution effects on materials including cultural monuments. Water Air Soil Pollut 85:153165. https://doi.org/10.1007/BF00483697

Kucera V, Tidblad J, Kreislova K, Knotkova D, Faller M, Reiss D, Snethlage R, Yates T, Henriksen J, Schreiner M, Melcher M, Ferm M, Lefèvre RA, Kobus J (2007) UN/ECE ICP Materials Dose-response functions for the multi-pollutant situation. Water Air Soil Pollut Focus 7:249-258. https://doi.org/10.1007/s11267006-9080-z

Kumari P, Toshniwal D (2020) Impact of lockdown on air quality over major cities across the globe during COVID-19 pandemic. Urban Clim 34:100719. https://doi.org/10.1016/j.uclim.2020.100719

Kużelewska E, Tomaszuk M (2020) European human rights dimension of the online access to cultural heritage in times of the COVID-19 outbreak. Int J Semiot Law. https://doi.org/10.1007/s11196-02009712-x

La Russa MF, Comite V, Aly N et al (2018) Black crusts on Venetian built heritage, investigation on the impact of pollution sources on their composition. Eur Phys J Plus 133:370. https://doi.org/10.1140/ epjp/i2018-12230-8

Lian X, Huang J, Huang R, Liu C, Wang L, Zhang T (2020) Impact of city lockdown on the air quality of COVID-19-hit of Wuhan City. Sci Total Environ 742:140556. https://doi.org/10.1016/j.scitotenv. 2020.140556

Lokhandwala S, Gautam P (2020) Indirect impact of COVID-19 on environment: a brief study in Indian context. Environ Res 188:109807. https://doi.org/10.1016/j.envres.2020.109807

Lombardo T, Ionescu A, Chabas A, Lefèvre RA, Ausset P, Candau Y (2010) Dose-response function for the soiling of silica-soda-lime glass due to dry deposition. Sci Total Environ 408:976-984. https:// doi.org/10.1016/j.scitotenv.2009.10.040
Multi-Assess (2010) Model for multi-pollutant impact and assessment of threshold levels for cultural heritage, Multi-Assess project

Nakada L, Urban R (2020) COVID-19 pandemic: Impacts on the air quality during the partial lockdown in São Paulo state. Brazil Sci Total Environ 730:139087. https://doi.org/10.1016/j.scitotenv.2020. 139087

Nakata M, Sano I, Mukai S (2015) Air pollutants in Osaka (Japan). Front Environ Sci 3(18). https://doi.org/10.3389/fenvs.2015.00018

Ortiz P, Antunez V, Martín JM, Ortiz R, Vázquez MA, Galán E (2014) Approach to environmental risk analysis for the main monuments in a historical city. J Cult Herit 15:432-440. https://doi.org/10.1016/j. culher.2013.07.009

Pei Z, Han G, Ma X (2020) Response of major air pollutants to COVID19 lockdowns in China. Sci Total Environ 743:140879. https://doi. org/10.1016/j.scitotenv.2020.140879

Pei L, Wang X, Guo B, Guo H, Yu Y (2021) Do air pollutants as well as meteorological factors impact corona virus disease 2019 (COVID19)? Evidence from China based on the geographical perspective. Environ Sci Pollut Res 5:1-13. https://doi.org/10.1007/s11356-02112934-6

Rajput H, Changotra R, Rajput P, Gautam S, Gollakota ARK, Arora AS (2020) A shock like no other: coronavirus rattles commodity markets. Environ Dev Sustain 23:6564-6575. https://doi.org/10.1007/ s10668-020-00934-4

Ren W, Chen X (2020) Evaluation of the online virtual reality $360^{\circ}$ world cultural heritage tourism under the charter on interpretation and presentation of cultural heritage during the Covid-2019 outbreak. Shanghai. https://doi.org/10.21203/rs.3.rs-79453/v1

Rovella N, Aly N, Comite V, Randazzo L, Fermo P, Barca D, Alvarez de Buergo M, la Russa MF (2020) The environmental impact of air pollution on the built heritage of historic Cairo (Egypt). Sci Total Environ 764:142905. https://doi.org/10.1016/j.scitotenv.2020. 142905

Sharma S, Zhang M, Anshika J (2020) Effect of restricted emissions during COVID-19 on air quality in India. Sci Total Environ 728 : 138878. https://doi.org/10.1016/j.scitotenv.2020.138878

Sicard P, De Marco A, Dalstein-Richier L et al (2016) An epidemiological assessment of stomatal ozone flux-based critical levels for visible ozone injury in Southern European forests. Sci Total Environ 541:729-741. https://doi.org/10.1016/j.scitotenv.2015.09.113

Singh S, Elumalai SP, Pal AK (2016) Rain pH estimation based on the particulate matter pollutants and wet deposition study. Sci Total Environ 1(563-564):293-301. https://doi.org/10.1016/j.scitotenv. 2016.04.066

Spezzano P (2021) Mapping the susceptibility of UNESCO World Cultural Heritage sites in Europe to ambient (outdoor) air pollution. Sci Total Environ 754:142345. https://doi.org/10.1016/j.scitotenv. 2020.142345

Srivastava AK, Bhoyar PD, Kanawade VP, Devara PCS, Thomas A, Soni VK (2021) Improved air quality during COVID-19 at an urban megacity over the Indo-Gangetic Basin: from stringent to relaxed lockdown phases. Urban Clim. 36:100791. https://doi.org/10.1016/ j.uclim.2021.100791

Temiz S, Salelkar LP (2020) Innovation during crisis: exploring reaction of Swedish university libraries to COVID-19. Digit Libr Perspect 36(4):365-375. https://doi.org/10.1108/DLP-05-2020-0029

Tidblad J, Kucera V, Mikhailov AA, Henriksen J, Kreislova K, Yates T, Stöckle B, Schreiner M (2001) UN ECE ICP Materials: doseresponse functions on Dry and Wet acid deposition effects after 8 years of exposure. Water Air Soil Pollut 130:1457-1462. https://doi. org/10.1023/A:1013965030909

Tleuken A, Tokazhanov G, Guney M et al (2021) Readiness assessment of green building certification systems for residential buildings during pandemics. Sustainability 13:1-31. https://doi.org/10.3390/ su13020460 
Uğur NG, Akbiyık A (2020) Impacts of COVID-19 on global tourism industry: a cross-regional comparison. Tour Manag Perspect 36: 100744. https://doi.org/10.1016/j.tmp.2020.100744

Venkat Rao N, Rajasekhar M, Chinna Rao DRG (2016) Detrimental effect of air pollution, corrosion on building materials and historical structures. Am J Eng Res 3:359-364

Vidal F, Vicente R, Mendes Silva J (2019) Review of environmental and air pollution impacts on built heritage: 10 questions on corrosion and soiling effects for urban intervention. J Cult Herit 37:273-295. https://doi.org/10.1016/j.culher.2018.11.006

Vitale M, Proietti C, Cionni I, Fischer R, de Marco A (2014) Random forests analysis: a useful tool for defining the relative importance of environmental conditions on crown defoliation. Water Air Soil Pollut 225:1992. https://doi.org/10.1007/s11270-014-1992-2

Wang Q, Su M (2020) A preliminary assessment of the impact of COVID-19 on environment - a case study of China. Sci Total
Environ 728:138915. https://doi.org/10.1016/j.scitotenv.2020. 138915

Watt J, Tidblad J, Hamilton R et al (2009) The effects of air pollution on cultural heritage. https://doi.org/10.1007/978-0-387-84893-8

$\mathrm{Xu}$ X, Chen P, Wang J et al (2020) Evolution of the novel coronavirus from the ongoing Wuhan outbreak and modeling of its spike protein for risk of human transmission. Sci China Life Sci 3:457-460. https://doi.org/10.1007/s11427-020-1637-5

Zambrano-Monserrate MA, Ruano MA, Sanchez-Alcalde L (2020) Indirect effects of COVID-19 on the environment. Sci Total Environ 728:138813. https://doi.org/10.1016/j.scitotenv.2020. 138813

Publisher's note Springer Nature remains neutral with regard to jurisdictional claims in published maps and institutional affiliations. 